\title{
EXISTENTIAL DEMOCRATIC INDIVIDUALITY: A Conversation with George Kateb
}

\author{
Individualidad existencial democrática: \\ Una conversación con George Kateb
}

\section{GEORGE KATEB}

Princeton University

\begin{abstract}
The interview took place at the Department of Politics, Princeton University, in two consecutive, two-hour long, morning sessions on January 14th and 15th, 2013. The interview was conducted by two professors of the Pontifical Catholic University of Chile: Tomás Chuaqui Henderson, associate professor of political science, and former student of Professor Kateb at Princeton and Diego Rossello, an assistant professor of political science, who obtained his Ph.D. at Northwestern University. The transcription of the interview has been edited to improve clarity and readability.

Key words: Kateb, individuality, democracy, existentialism, Emerson.

\section{RESUMEN}

La entrevista se realizó en el Departamento de Ciencia Política de la Universidad de Princeton, en dos sesiones consecutivas de dos horas cada una, el 14 y 15 de enero de 2013. Realizaron la entrevista dos profesores de la Pontificia Universidad Católica de Chile: Tomás Chuaqui Henderson, profesor asociado de ciencia politica, quien tuvo al profesor Kateb como tutor de tesis doctoral en Princeton; y Diego Rossello, profesor asistente de ciencia politica que obtuvo su doctorado en la Northwestern University. La transcripción de la entrevista ha sido editada para lograr una lectura más clara y fluida.
\end{abstract}

Palabras clave: Kateb, individualidad, democracia, existencialismo, Emerson. 


\section{SESSION 1}

Diego Rossello: So, I have a first question, just to break the ice a little bit, and it is a very open one. How did you become interested in political theory?

George Kateb: Yes, I think that question I can answer more or less clearly. I entered Columbia University in the fall of 1948, and I graduated, therefore, in the class of 1952. All my degrees are from Columbia. I had two freshmen teachers who made a great impression on me. The first was Mark Van Doren, a poet and a scholar of Literature and probably the most influential teacher I've ever had. He taught the freshmen course in the literary humanities. A man from the Midwest, and having this simplicity of character of a Midwesterner, and yet having superlative intellectual refinements to go with the simplicity of manner -it is a very tough combination to beat when you have that. He also looked like the actor Joseph Cotten... And he was just a tremendous teacher talking about Homer, and Herodotus, and Plato of course, and such good writers up to and including Pascal. He had a tremendous influence on me, in directing me in my growing interest in the reflection on -I don't know what else to call it- on people, on human life, on the human condition, how to make sense of it, of what to look for when you are thinking about it, on who can help you to refine and enrich your thinking about it as you get older and older. And he has stayed with me: still I remember... things... still, that he said in class.

The other teacher was not much older than I was, and I was 17 years old. He was perhaps 23 or 24. His name is Peter Gay, the famous historian. And he taught me as a freshman in the core curriculum what was called "Contemporary Civilization". But it wasn't contemporary at all, it was civilization beginning in the middle ages, and going through to the 19th and 20th centuries. Gay was a political theorist, and he wrote his dissertation on Eduard Bernstein, the revisionist Social Democrat in Germany. And he taught "CC", the "Contemporary Civilization" course, four times a week. It was a very demanding course with lots of reading, and he helped open up the reading. The tendency of his mind was moderate critique of everything. And I think that was probably true of the whole Columbia University Faculty at this time. But he taught the texts to me for the first time, and then taught a sequence that I took in the History of Political Thought, a double course. So I suddenly found myself more interested in political ideas than in anything else. I thought, "Should I not go in the direction of Literature?" And I said to myself: "Unless you write poetry, or fiction, or drama yourself, it is better not to concentrate your study on poetry, fiction, and drama". It is a strange thought, I guess. Most people who do teach Literature are not practitioners of it. But that is what kept me out. Though over the years, of course, I have read some Literature: American, English, French, some German, and others. Tolstoy had a powerful impact on me as a young fellow, War and Peace (2009).

So these are the two teachers who set me in this critical-humanist direction, interpreting the human condition. That is how, I suppose, I would put it. And that has stayed with me all these years. Now, there were other teachers at Columbia when I was an undergraduate whose courses I took and who affected me. One was C. Wright Mills, the radical sociologist. He taught a joint seminar with a good liberal named Charles Frankel. That had an effect on me. But I took other courses with both Mills and Frankel. I took one course anyway and audited another with Jacques Barzun -I assume that name is familiar- and I audited particular sessions taught by Lionel Trilling, a truly great teacher. These were all people who took their teaching with the utmost seriousness, even though they were well published scholars, and men of letters. So it is to Columbia College that I owe cultivation of an interest in political theory and then continuous enrichment of it by the people there. In graduate school I worked with Franz Neumann, a colleague and a great friend of Herbert Marcuse. And I took a course with Marcuse as a graduate student, and I found that they added perhaps a bit of radicalism to what up till then had been a very good-natured liberalism. And it's Marcuse's passion that stays with me still. Humorless, absolutely humorless; utterly serious. Not receptive to questions especially. But he had something to say and said it. Marcuse... very impressive. Franz Neumann was the seminar leader for the graduate students in political theory. A powerful intellect, he was a lawyer for the Social Democratic party in Germany before he became an émigré. His book Behemoth (2009) on Nazism is still a classic, and he wrote other things as well. 
Columbia then, I believe, was the greatest American university in the 30's, 40's, 50's. Then began a long decline. Never, however, sinking beneath a high level. And now it is ascending again I am happy to see, and thanks to a universally disliked president Lee $C$. Bollinger. I think he is the best thing that has happened to Columbia in my life time. When I was an undergraduate, Eisenhower was president of the University, and he was a benign, remote presence. He didn't do anything to harm Columbia, but somehow, when the neighborhood changed, the University changed. But it has recovered, like the rest of New York City. Whether it awaits decline again, I don't know. It would seem that among great universities only Harvard never seems to decline. Though it is not uniformly great. It just isn't! But they have a puritanical tenacity of vocation and they take their motto, Veritas, very seriously: they don't let anything get in its way. They make mistakes, of course, both in not hiring, and hiring, but that's another story. In any case, I find it important, speaking about myself, to refer to the impact of Columbia University.

Tomás Chuaqui: This period of time also saw the rise of the scientific, or supposedly scientific, exercise of political science. I was wondering how that affected you, if at all. Were you engaged with the Political Science department which was moving in this direction, or not? I ask this because I also want to go back to this book Political Theory: Its Nature and Uses (1968) which you published in 1968.

George Kateb: I have always thought of myself as a Political Scientist, and always thinking that Political Theory is in itself an independent Political Science, learning where it can from Political Science properly speaking, or improperly speaking, as we go along, but able, through the force and greatness of the canon -and here I admire Leo Strauss for insisting on this point-able to do justice to political phenomena in the way that much professional Political Science does not. However, at this time (I left Columbia in 1954) the department was still humanist, mostly all prose, and very good prose. David Truman, Lindsay Rogers, Wallace Sayre, and others all wrote good English and the quantitative and then the formalist tendencies were really not very much going in the early 50s. Even Robert Dahl's work had really not begun by then. (I am that old, I graduated that long ago). I mean it had not yet begun. However, of course, I spent my life in Political Science departments; I am not a philosopher and I count myself as one of the many people who are political theorists, but based in Political Science departments, emphatically insisting that the essence of Political Theory is the study of, and reflection on, political life, and not seeing political life as an accidental illustration of mathematical or scientific techniques and interests. Therefore, I do not deny that I owe my livelihood to Political Science but I do not feel sympathetic to anything but a humanist approach to understanding it. Now, does that rule out the use of quantitative methods for certain purposes? No. But then the purposes are temporary. Predicting elections, say, or sampling public opinion. All these phenomena are ever changing, and those methods can't keep up with the ever changing phenomena. But if I have been extended tolerance in departments where the majority of people are political scientists I will extend it in return.

I did teach in Amherst College, for 30 years, 1957 to 1987. I had no graduate students, except for one visiting term at Harvard, and that, in 1986, persuaded me that I had been missing too much teaching just undergraduates; so, coincidentally, Princeton came through with a bid in 1987, and I accepted it, with some reluctance. I accepted it above all because this would give me first rate graduate students. Sheldon Wolin had left angry over departmental politics and Amy Gutmann took over, and with the help of Fred Greenstein in American Political Parties and American Politics they re-organized the Political Theory offering. So in 1987 they made offers to Steven Lukes, Alan Ryan and myself. Lukes took a long time to say no, as he did with Columbia. And Ryan and I said yes and came. I came in the Fall of ' 87 , he came in January of '88. Ryan then left to become Warden of New College and then came back here, where he is now, on a temporary appointment as a Senior Researcher, a Lecturer with the rank of Professor. This is a political science department, and ever more so. At Amherst College, which is where I began, nobody was a political scientist, in the quantitative or formal sense. Everybody wrote prose, and that tradition continued after I left and it is still intact. A visiting committee at Amherst College said recently that "you have to acquaint your students -well, at least acquaint them- with what is going on in Political Science", and they just rejected the idea, though politely. So they maintained adamantly their humanist 
orientation. Though a number of them are skillful in these techniques they don't use them, and they certainly don't teach them. I think that is generally true in Liberal Arts Colleges in the country: Williams, Wesleyan, Pomona...

Look, I am going on too long. I want to say that the relation between Political Science, academically understood and professionally understood, and Political Theory, based in Poli-Sci departments -not Political Philosophy; Political Theory because it is based in Poli-Sci departments- these relations have been tense for a long time and they will continue to be tense. Most of the positions go to Political Science, but it is the sign of something holding on that any effort to crowd out Political Theory entirely, or relegate it to one or two positions, is rebuffed in every first class American institution. The hold of Europe, and Oxford and Cambridge is still pretty strong in the American Academy.

Tomás Chuaqui: Would you say that the writing of this book, Political Theory: Its Nature and Uses, had to do with that effort to sustain the presence of Political Theory in Political Science departments?

George Kateb: Yes. I thought that something could be said about the uses of Political Theory, as the subtitle suggests. It's strange: this book, not in print anymore, is not regarded by anyone, except, oddly enough, by Political Scientists, who think that they can, in a kind of bargain-basement way, acquaint themselves with the stuff of Political Theory. So now and then somebody who really has a high reputation in Political Science, but not in Political Theory says, "Well, I thought your book sort of taught me, or told me, what I wanted to know about this subject". Boom! That's it, and I don't have to think about it anymore (laughs)! But if it somehow enlisted their sympathies for not getting rid of Political Theory from their departments, I am content that the book served some purpose.

Tomás Chuaqui: And you think that they actually are sympathetic to it? Because I was reading its last pages and I was thinking of political scientists reading this and...

George Kateb: Yes, it is not for political scientists, not the last chapter (laughs).

Tomás Chuaqui: In this chapter you use the terms "concentrations of sensibility" which might be particularly alien to a political scientist. I actually lent this book to, as you say, a political scientist who wanted to learn a little bit about what Political Theory is all about, and he hasn't really come back to me saying much yet...

George Kateb: Yes, right, they probably begin reading at the beginning and then the end. The beginning is okay, but then the end is, sort of, literary and precious and, I know... unpalatable.

Tomás Chuaqui: No, I think it is wonderful, but actually I wanted to ask you about that. Would you still make that argument about the accumulation of sensibilities, and the importance of sensibility, in the authors of the canon as central as you make it out to be in this text? Even more so than the arguments presented themselves; that is what you call a "sensibility", no?

George Kateb: Right. The great books in the canon, each of them represents the manifestation of an outlook on the human condition, human life, and the place of politics in that life. There is an outlook which seems to permeate any particular aspect of the theory as a whole. The outlook, then: let's reconstruct the possibility of an argument here. The outlook the theorist has to begin with; the outlook is a kind of systematic preconception, and on further reflection, and on the effort of spelling out this outlook, finds the outlook probably changing a little bit as he or she goes along in constructing the theory. I would stand by... yes... I would stand by that. I still think that all the great books in the canon manifest an outlook that you could then restate, but not in their words, exclusively. Some kind of orientation that has to do with what you should hope for, what you should expect, what disappointments you are likely to encounter as you observe political phenomena, and what traumas and ferocities you sense will manifest themselves politically. And yes, I think that is right. I have a few glib phrases that I remember: do I not say "world-hating Plato"? Is it somewhere in there?

Tomás Chuaqui: Yes, I think so... it is in Plato's description in there...

George Kateb: Yes, a "concentration of sensibility"; that phrase I don't even remember ever using, but good, if you say I did then I must have... By "sensibility" I mean "outlook" or "orientation", and it precedes, and it expresses, and it is refined in the expression; and then it is imparted. And 
the point of the study of political theory is to absorb as many -we now use the Nietzschean word: "perspective" - as many perspectives as possible: "keep them all, do justice to all of them", Nietzsche says in a great passage on perspectives in Genealogy of Morals (2013). That is really what I have lived for. The absorption of many perspectives, trying myself to take pleasure in them, to learn from them, to balance them, to oppose them to each other, to distill from them something not in their own language that I can express in my own. I believe in, as Judith Shklar did, Political Theory as restatement; "free, indirect discourse" is what literary critics call it. You become the thing you are describing but you change it as you describe it. That is interpretation. So, what is Political Theory? It is the interpretation of perspectives.

Tomás Chuaqui: Couldn't one say that that is the sensibility that comes through out of reading your work as a whole?

George Kateb: Ah, you want to turn this argument against me.

Tomás Chuaqui: Not against; in your favor.

George Kateb: Oh, what an aggressive remark that was (laughs). Very good. Well, you mentioned in our correspondence that you seemed to detect some kind of consistency, or unity from the start.

Tomás Chuaqui: "Unity" is better than "consistency" I would say.

George Kateb: Unity? That is the word you used in fact, I remember. Well, now, look, I would ask you if you would say -here you would assist me and, if you will, you would do to me what I have done to others... not that I am putting myself in the canon, but, you know, there is writing out there, and it asks to be read and therefore with the expectation that it will be interpreted, and used, and misused, and abused. Let me ask you, how do you describe, if you would, this unity, and I will tell you whether I think it hits the mark.

Tomás Chuaqui: I think certainly the word "existential" would come into whatever description I would propose.

George Kateb: Ok, French existential?

Tomás Chuaqui: French existential? No, your work contains a rather stranger combination.

George Kateb: Or German existential?

Tomás Chuaqui: No, I would say it is American existentialism.

George Kateb: Oh!

Tomás Chuaqui: A very much, sort of liberal-American existentialism.

George Kateb: Emerson?

Tomás Chuaqui: Emerson, of course.

George Kateb: From the start?

Tomás Chuaqui: Well, I was surprised not to see much of Emerson in Political Theory: Its Nature and Uses (1968)...

George Kateb: There is some...

Tomás Chuaqui: There is one reference to him....

George Kateb: Yes, the essay on Plato in Representative Men (2004)...

Tomás Chuaqui: That's right, exactly.

George Kateb: I have been reading Emerson a long time, however, even as an undergraduate.

Tomás Chuaqui: Would you agree with what I said about using the terms "American existentialliberalism" or something of this sort to describe your work? And by existential I mean something of what you said before, this concern about human behavior, human nature, human relationships, and what makes life worth living, in a certain sense.

George Kateb: Right. As long as you don't deny the impact on me, which was quite heavy in my mid to late twenties, of Sartre and Camus, and Malraux: I read all Malraux's novels, including the most precious earlier novels, and some of his other prose. I read a fair amount of Sartre, I read the entirety of Being and Nothingness (2003) which I certainly do not regret. And I read a lot of 
Camus, and wrote maybe a hundred pages on Camus, some of which have been published and the others moulder in my file cabinet. I thought there was a richness in the French writers, and a seriousness there that is not found much in American existentialism. And here is the reason: French existentialism is atheist and mortalist, and this is not found in the American tradition. And I took that with the utmost seriousness. And then in middle years I kept on teaching Nietzsche. When you were a student here did we assign Nietzsche in any of our grad seminars? Do you remember Nietzsche at all?

Tomás Chuaqui: In the Proseminar I took with you I don't think we read Nietzsche. I read Nietzsche with Alexander Nehamas in the Philosophy Department.

George Kateb: There you go. OK. Nietzsche and then, Heidegger... I think, as I get older and older, it is Heidegger who really stays with me. He has real seriousness. He sometimes mystifies, but he never drops the thread. I don't think he does. So, the short answer is, existentialism, in some sense or other, yes, but don't omit existenz philosophy in its Continental forms. Not too much Jaspers, but certainly, if you will, Nietzsche and Heidegger, and then, in France: Sartre, Camus, and Malraux. So, if you are willing to allow me to annex the bleak godlessness of both the French and the Germans, then I would accept your general characterization. I would not put too much weight on the word "liberal", however, because that generally means John Dewey, concerning whom I have many reservations. I would rather speak of "democratic individuality", which is basically Walt Whitman's phrase.

Now, was it present at the beginning? No. I mean the first book I wrote was Utopia and its Enemies (1988), a revision of the dissertation, and so here is how I would supplement your characterization of my outlook, or concentration of sensibility, or orientation: I have always been... and I think it is true in general of American political theorists, that they are "mama's boys" and they are therefore very sensitive to the pain of others. So I really have considered myself more and more as a "political pathologist", or even "oncologist". I find mostly horror in any concentration of political power invested with either charisma or legitimacy. And, therefore, Emerson can't possibly be enough. Really not even the continental existentialists. The horror is represented better by Hannah Arendt than by anybody else in the Twentieth Century. So I have been... I've tried not to be limited by either liberalism or the American tradition, while being nourished by both. And looking outside of the United States for certain hard, serious work that American thinking seems to have been incapable of, and may still be incapable of, which is why Continental thinking has such an attractiveness for some, like Bonnie Honig. You might say that the root of my interest in Political Theory is concern over the amount of irrationality and cruelty prevalent in politics, and not just the terrible dictators, but also in the United States itself, not to mention the UK and its imperialism and its insolence, and France and its cruelties in North Africa and in South-East Asia. I take human suffering seriously and I was sensitized especially to that by Simone Weil, whom I read in my early twenties. I read practically everything available by her. That was a time when I could read French almost as easily as I could read English, and I translated one of her books completely, never published, except in part. I am not going to pretend that I have unaccented French, so I will just say it in anglicized French: Intuitions Pré-Chrétiennes (1951). It has been translated by others, published, but never completely. It is a great book! And it's all about the affinity between Platonism and Christianity. But it's mostly about suffering. Her great essay translated by Mary McCarthy, "The Iliad, or the Poem of Force", (1981) had a profound effect on me. This, at the same time that I was reading Sartre, and Camus, and Malraux.

I am not exactly eclectic, but I try to be as open-minded as possible. Yet always this large top of the funnel narrows, narrows, narrows, and at the bottom is an abyss; it is a hole, and it is the bottomless human suffering that I then try to send up out again. That is really the key to my orientation. I do everything that Nietzsche said you are not supposed to do: I concentrate on suffering.

Diego Rossello: We should go back to the Dewey issue, but I would like to leave him between brackets for a while. You said that you have been very influenced by the existentialist philosophers, you mentioned Sartre, Camus, you mentioned Heidegger, very strongly. But your work is usually credited with the fact that you find what is important in Emerson and Whitman for Political Theory. 


\section{George Kateb: Yes.}

Diego Rossello: And you said you were reading Emerson even as an undergraduate, but I wonder if you were doing so because you were acquainted with the American canon, or if there was some discussion at the time about Emerson and Whitman as relevant authors for political theory?

George Kateb: No, there wasn't any.

Diego Rossello: Ok, so that's you entering into this conversation, right?

George Kateb: I think I may have spoken too dogmatically... as Tomás will tell you, that is one of my many besetting sins. But, no, I was interested in Emerson when no one else I knew was interested in Emerson.

Diego Rossello: And you were interested in Emerson for reasons related to Political Theory.

George Kateb: Yes, but remember why I was interested in Political Theory to begin with. An outlook on human life, the human condition, from a perspective, however, of what makes people go and what makes people do the bad things they do, as well as, perhaps, good things. So, yes, go ahead.

Diego Rossello: Do Emerson and Whitman provide a non-mortalist existentialism that you find provocative or important for Political Theory?

George Kateb: I don't think either one of them believed in an afterlife. So at least that much they learned, but they still thought that there was a kind of divinity permeating the world or the universe. They were not atheists and they had religious expectations. They were not Christian. As I say, they did not believe, so far as I can tell, in God as a man with a white beard, who said "let there be" and then there was. However, they did not accept Epicureanism: matter and void. They thought that there was something else; that the world was too beautiful, to have been accidental. For all of them it is the beauty of the world, finally, that convinces them that the world is not a product of accident. But their knowledge of the millions and millions and millions of years that preceded the taming of the Earth by natural forces to make it this beautiful blue globe and where nature existed in indefinitely large number of forms... they had no sense, I don't think, of the hundreds of millions of vacant years before life emerged. With all that waste, you want to say to them, how could you possibly believe in "The Maker"? What a moron he must have been! To let all of this, all of this exist without any mind in it! It's not seven days of creation, it's... I don't know! How many billions... How old is the universe? Is it 14 billion years old? It may not be the first universe either. This sense of the vastness of time -they had a sense of the vastness of space; at least it was incipient- but the vastness, the greatness of time, that's not in these great American writers. It is scarcely present, really, in any political theorist or political philosopher, if you want to extend it. So, it's therefore clear that I could not ever accept the American line as sufficient.

Tomás Chuaqui: Listening to you before talking about the French and German existential aspects of your thought, I was having trouble fitting Whitman with that, putting those two elements together. I of course admire Whitman very much, but I have trouble with his... maybe one should call it "optimism", no?

George Kateb: Yes.

Tomás Chuaqui: He's an exuberant optimist and I don't see how this fits with your focus on human suffering and so on; so if you could say something about that...

George Kateb: Well, that's a very hard question. I guess the glib answer would be, you just can't live on the negative, it's not a sufficient "diet". Here I would invoke the name of Thoreau, whose sense of evil was far more profound than that of Emerson or Whitman. He really took the institution of slavery to heart, in a way that Emerson and Whitman did not, until Emerson did eventually, and Whitman, you might say, never did. So, in Thoreau you have this combination which, I think, I'd be very happy to subscribe to. And that is that you must somehow take into account the undeniable beauty of the world as we know it, and the indefinitely great human capacity to do evil. The beauty is there, but, Thoreau says, your perception of it will languish if your conscience is active. It is only if you act on your conscience, in order to try to do something about the evil, that you'll have then come into the possession of the true perception of beauty. It is that complicated inter-connection between the positive and the negative that I find best 
exemplified, if not always explicitly stated, in Thoreau. Emerson can't quite handle it. He has an essay on tragedy in which he says "Well, black slaves get inured to their pain and they don't even feel it after a while". Now, he is impersonating; he is impersonating the tragic sensibility, trying to say that nothing really is tragic finally. He is impersonating it. I don't know whether he really believed it, he had so many personal losses in his life: the crushing impact of the death of the first woman he loved and of two of his brothers, and his five-year old son, and so on. He also wrote great, great essays on slavery after this cold essay on the tragic or tragedy. Emerson's anti-slavery writings are a magnificent contribution to American political thought. However, the balance between the need to appreciate beauty and the need to be sensitive to evil -natural beauty; human evil- Thoreau is a great exemplar of that outlook and I guess I have tried to do justice to the world by acknowledging its beauty, including the human world, though Thoreau never includes it. The formulation I used in Human Dignity (2011) I would stand by: the works of humanity are far greater than the days of humanity, right? The work we do is much better than what we are, morally speaking.

Tomás Chuaqui: I'm afraid to ask this question, but in a way what you just said reminds one of Augustine as well.

George Kateb: Yes. As great a Political Theorist as almost any, but not as great as Plato, who remains, I think, the greatest. There Augustine is: everything is in him, even if tainted by his religiousness, but the greatness keeps on breaking through. My God what a mind he had! Go ahead...

Tomás Chuaqui: I just read a review of Human Dignity by Ryan Anderson in First Things (2012), which is a Catholic journal. Did you see that?

George Kateb: Oh, well, somebody had the bad taste to refer me to it (laughs). They called it a slam except for the first sentence. I said, well, I don't need to take another slam, so I just read the first sentence (laughs).

Tomás Chuaqui: Well, the word Anderson uses is "infuriating".

George Kateb: Yes! A very flattering word. But tell me, what... what infuriates him? That I'm... that I'm... not religious, that I'm secular.

Tomás Chuaqui: That you are trying to make a secular argument... which requires religious backup...

George Kateb: Who said, who said so?

Tomás Chuaqui: The author, Anderson, of the review in First Things! I'm sure that many people would actually say the same thing. If you are going to talk about human dignity, or about human existence in general and its value, in contrast with the goodness of the world -that's why I mentioned Augustine- you need that kind of back up. And if you don't resort to it you are somehow... cheating, as it were.

George Kateb: Maybe, but that's a harsh word. I would say the religious element is either redundant or misleading. It is infantilizing at its worst. Look: here the world is! It wasn't made, it is incredible, just look at all the waste around it, over time and in space. It is quite likely there is no other intelligence in the whole universe... No: nobody has the right to say that. It is quite possible that there is no other intelligence. Isn't it amazing that this dumb ape becomes a human being who could develop language and then, and then, say with God: "it is"? This is incredible! Why... why, why do you want God to muck up the works? He made, He solves, He pretends... the notion of God pretends to solve problems! The problems are not meant to be solved. There they are, there it is; there the world, the universe, is. Try to understand it. What does God contribute to it? The role of the magician. But this is infantilizing.

Diego Rossello: What brought you to be interested in utopias?

George Kateb: Again, this sense that the world is too full of suffering. And wouldn't it be nice to have a defense of the idea of utopia; nothing more. Wouldn't the world be better off without suffering and war? Systematic material immiseration, on the one hand, and war, on the other. So, one chapter is on the defense of perpetual peace, and I take up the arguments including Hegel's, that war is positively good, and I try show that this will not do. Then another chapter, I think, is on guaranteed abundance, I think that is the phrase I used. And, well, what can you say for poverty? 
And I finally said, the only reason to defend poverty is aesthetic and that is not good enough. I quote Edward Bellamy to the effect that some want poverty to continue as the background for the golden few, and the gold of the golden few is all the brighter because of the bleakness and darkness of the background. I love the sensibility being displayed in this idea, which Bellamy hated and yet, notice, expressed as well as anyone has ever expressed it. Well, while, trying to deride it. So, why did I go to utopias? As relief from what I took to be the terribleness of life. I mean, this was written in the late 50s, very close to the Second World War, with all its cruelties, including the atom bomb, two atom bombs; then the liquidation of the Jews of Europe; and the Nazi occupation in many countries, often brutal. Then, the horrors in the Soviet Union, which I guess I was a little less sensitive to than to Nazism, but that also had its effect. So there was a vibrant anti-utopianism, represented by thinkers like Camus and Popper, and Aron and some others. And I said -you see, this is how heartless a graduate student can be- "This is the subject". It really interests me, but why does it interest me? The root is always some concern with the awfulness, not just the greatness, but also the awfulness of reality. You can't be a realist unless you look at the worst. Political theory keeps you addressed to the worst. That's why it is an independent Political Science. That's not true of academic Political Science; they are very at home in the middle. And they are blind to what they consider to be "marginal experience", but the marginal experience is the central experience for most human beings: want, desolation, unhappiness are real; premature death, violence, always violence... how Americans love... how The New York Times loves the American use of violence. You just look at today's headline about the French in Mali. Hurrah, hurrah! for the French for going in violently while the US exercises caution, as if to say that Obama is a kind of fruitcake... terrible...

Tomás Chuaqui: I think I remember you once saying that one of the things that one ought to do when reading a text of the canon -and not only of the canon, actually-is to be sensitive to the worst possible consequences that a text may have. I wonder if you could say something about that. I am hearing you now, and it seems to me you would extend that even beyond the reading of texts, but also to, I don't know, ideologies, outlooks, and so on...

George Kateb: Yes, I believe, though I'm not sure I've ever said it, that every one of the great or good works in Political Theory can have bad consequences, if they are taken too literally. There might be some exceptions to this... off-hand I can't think of any, and the generalization includes Mill, who was horrible about peoples of Asia, for example. It includes Tocqueville, who celebrated the French invasion and conquest of Algeria, on grounds that it was good for French morale. It goes for John Dewey, who said that the engineer, this during the great depression, is the model political actor... horrible, a horrible thing to say. It goes for Plato, who was willing to relegate the great majority of the population to being servants, and to diminish and infantilize servants of the minority. It goes for Aristotle, who believed in natural slavery, even though it wasn't the slavery that was practiced by Greece, he still thought that some people deserved to be slaves, for they were northern Europeans, who were strong and stupid; or Asia minor people, who were intelligent but cowardly. In Augustine: he accepts slavery... and war! He helps to invent the notion of the just war, one the great follies of academic discourse. It goes for Aquinas, he accepted slavery... and so on. Is there anyone whose work isn't potentially lethal or sinister? Now, we are talking about the canon, as well as the XX century candidates for canonization, like Hannah Arendt and Michel Foucault, Jean Paul Sartre, Simone Weil. Let's call it the canon and the candidates, the canonized and the beatified... is that the gradation? Could you name one who is not potentially lethal, in influence?

Tomás Chuaqui: Rawls?

George Kateb: He has no theory of foreign affairs until he comes to The Law of Peoples (2001) and that is a terrible, terrible, surrender to multiculturalism. And that's, that's the book that's having the influence these days. Name another?

\section{(Pause)}

George Kateb: Either canonized or beatified, or must we conclude that they are all guilty of potentially lethal influences? 
Tomás Chuaqui: But would you say that if that is the case, it has to do with what John Stuart Mill says about Bentham, in the Bentham essay (2003), which you cite: his comment about the "oneeyedness" of the authors of the canon (1986)? Is that why we need "two-eyed" commentators, in order to see the...

George Kateb: Wow! he didn't make that distinction. That's lovely! How good it is!

Tomás Chuaqui: Well... I just made it up. (laughing)

George Kateb: Well, you think I think you are rehearsing your lines? No, of course you just made it up! What is a conversation, if not improvisation? (laughs) Yes; I think I would accept that. It's only the commentator that can pretend to take everything in, but no commentator ever does. There's always something more. You know that poem by Robert Frost that Robert Nozick cites in Anarchy, State, and Utopia (2013) -a book still worth reading-called "The Armful", (1928) and it's about a person carrying a lot of things at the same time and one keeps dropping out, and he stoops to pick it up, so that he can get hold of everything, and then another drops. That's what the best "two-eyed" person can hope for, you're always forgetting a major element or phenomenon, right? You can't, the armful can never be complete. Can you aspire to more rather than less comprehensiveness? I guess, I guess you can. Yes, some try, some don't.

But return to the canonized and the beatified. Can you think of one?

Diego Rossello: Would you include Hannah Arendt among the thinkers who could have bad consequences?

George Kateb: At least she is aware of most of bad things; give that credit to her. Not just the plight of the Jews, but the suffering of other peoples. However, she does discourage interest in the question of poverty, I am afraid. In that sense she is very Nietzschean... but she is better on evil that any other Twentieth Century thinker, I believe. That is a great achievement! Not appreciated by most people, because they think that evil, again, is marginal and not central.

Tomás Chuaqui: But the way you phrased it before: it seems as if you meant to say, and correct me if I'm wrong, that, more often than not, these evil consequences are unintended consequences of the theory.

George Kateb: Not always unintended. When Hegel defends war he means to defend war; when Augustine permits slavery he means to permit slavery. He hopes, I assume, that the Church would never have slaves, though it did. But he permits slavery, and attributes it to punishment for our sins.

So, is there any work of literary greatness that does not have potentially lethal influences? Leaving aside political theory now, the beatified and the canonized...

\section{(Pause)}

Tomás Chuaqui: Well, when one thinks about literary works it seems to me there are different considerations in the sense that you learn about evil from literary works in a way... that is different from how you learn about evil in political theory. I mean, a literary author may write about evil, but not expecting it to be applied, but rather for you to learn about it and avoid it. Well, that's not necessarily the case in political theory, I would say. So there is a distinction.

George Kateb: Right on... right.

Diego Rossello: But literary works seem to be a very important presence in your work. You are providing us with examples of literary figures, and you are discussing and working through literary works, and of course that's connected with your humanist take on political theory. But would you say that a strong presence of literature in the writing of political theory has been the most appreciated form of doing political theory? Because there's another strand, perhaps, that has acquired greater prestige lately; perhaps I'm wrong, but it has more of an analytical tone to it, and proudly so. And so, what do you think is to be lost and what is to be gained by engaging in this literary conversation, from the point of view of political theory?

George Kateb: The danger might be that you lose sight of your principal area of interest, namely political life. And trying to understand it, in its structures or systems, in its procedures and processes, and in its continuous, continuous emission of action and policy. That has to be the center 
of your reflection. Whatever goes into your capacity to reflect, that has to be the area of inquiry. So, for example if you start -I don't think it happens too often- but if you start developing an interest, say, in writing about movies, which is, again, a growing tendency among not only political theorists but philosophers, you take your eye off the ball, to use an American colloquialism, on the one hand. Here is the other hand: you might diminish the work of literature by making it too usable for your own interest, even when you keep your eye on the ball. So, one must respect the political life as the core of your interest, and never, never forget that. And on the other hand, if you employ, in understanding the questions of political life -by means of political theory- if you employ a literary work like, say, Camus's The Plague (2008), Melville's "Bartleby, The Scrivener" or "Billy Budd" (1986), or Moby-Dick (2008)! - there's a whole new book called A Political Companion to Herman Melville (2013), much of which is on Moby-Dick-, if you do that exclusively as a political theorist I think you are taking your eye off the ball, on the one hand, and on the other hand you are transforming a literary work into simply another text in political theory. Does that... am I being coherent now?

Diego Rossello: Yes, you are. But, still, I was thinking about your own work in these terms. You find in Whitman resources for thinking democratic individuality...

George Kateb: I do.

Diego Rossello: ...that perhaps you are not able to find in any other author.

George Kateb: Ah, I see. Suppose non-political theory does the work that political theory should, but doesn't. Is that what you are saying?

Diego Rossello: Yes, yes.

George Kateb: I know Bonnie Honig thinks that, your teacher. I know Judith Shklar, who was Bonnie's colleague for a number of years at Harvard, also thinks that. And there are quite a number of other people in political theory who think that the canonized and the beatified, taken together, still don't do enough political theory; that literature helps. And I say, yes, I agree, I plead guilty to that inclination. However, I want to make sure that I don't rough up the works of literature, on the one hand. And on the other hand I want to make sure that I stay attentive, even as I use these works of literature, to political questions. Very hard balance to sustain. It's made easier when a political theorist writes about works of literature that are political, as for example, works by Orwell, or Conrad, or George Eliot, or Camus. And there are political novelists! Dostoyevsky, Stendhal, and so on. And one gets entangled, and after a while you have to say -after a whileyou have to say, look, here is something I think is interesting and I'm going to study it and write about it, and eventually I'll get back to political theory if I seem to be departing from it, after a while. But then after a longer while you say, now wait a minute, have I strayed too far in the direction of not being political, or in the other direction of making literature too practical? I must stop it. Or rein myself in.

Tomás Chuaqui: When you said that you ran the danger of taking your eye off the ball, did you mean that by focusing on literature you focus on fiction rather than on real life?

George Kateb: It's not quite that. Focusing on life, real or fictional, that is not political.

Tomás Chuaqui: One could also, I think, claim that the uses of literature for political theory have much to do with the representation and, say, the incarnation of the virtues and the vices.

George Kateb: Yes, that's what Shklar used it for in her great book Ordinary Vices (1985), right.

Tomás Chuaqui: And political theory is short on that in a certain sense.

George Kateb: I think it is, that's why she wrote that book.

Tomás Chuaqui: But could you say something about what works of literature have embodied what kind of virtues? For instance, I also remember you saying, at one point, that you admired moderation as a virtue. Just to give a few examples. I was surprised, for instance, that you mentioned Conrad since the virtues he admires, I personally find very problematic, like loyalty, which is at the very top of his list.

George Kateb: He can't be a complete guide to the moral life... 
Tomás Chuaqui: So, if you had to draw the map of the virtues and vices that you have distilled from literature, where would you go?

George Kateb: Again, a very good question and a very hard one. I guess I would never commit myself to any one literary writer as doing all the work that had to be done. And, again, I would learn where I could, from this writer and that. There's no doubt about it, especially if you are interested in what I call moral psychology, the virtues and the vices, but also other character traits. If you are interested in that, yes, you will be interested in literary works but you would not hope to find all that you are seeking in just one author or one book. Obviously some books are more important than other books for this enterprise. I would say Proust is of commanding importance. The indirect relevance to understanding political life is quite considerable if you read Proust, or Henry James, who was rarely political. When James is explicitly political in his novels he is far less interesting than he is when he is dissecting everyday transactions between human beings, and showing how human beings use each other. He never gets to torture and atrocity, no, but stays with using: he is all about how people use each other. That is of, at least, indirect political interest. Henry James is the greatest writer on that theme, I believe. And if your political theory includes respect for Immanuel Kant, including the Groundwork (1998) and the second statement of the categorical imperative, never treat another person merely as a means but always as an end, Henry James gives you book after book in which people treat each other not as ends, but as mere means. There is, however, in Henry James, in practically every case, at least one character that is an exception to that; they generally suffer, and are used most badly. Even as the wicked use each other, they also use the good ones: Isabel Archer in The Portrait of a Lady (2012), and Milly Theale in The Wings of the Dove (2008). These good people are too good for the world, and they are used. They know eventually that they have been used by being pursued for their money. Isabel catches on but stays loyal to the husband who used her; Milly also dies disabused but leaves her money to the man who betrayed her. And neither is consumed by bitterness: they triumph over having been used. Magnanimity is their virtue.

Tomás Chuaqui: And what about versions of democratic individuality? Where do you find those in literature?

George Kateb: I think practically any American book is going to show certainly the positive individuality component: people breaking loose, cutting themselves free, starting again, experimenting, demanding that they be treated as human beings. All of these are components of democratic individuality, and much of American literature is about the positive, of the three aspects, the positive. The authors sometimes practice the third, the impersonal reception to all sorts of phenomena ${ }^{1}$ I think Faulkner is a great example of that among American novelists. Negative individuality: resisting out of conscience... You better help me out. Does some American work of fiction strike you as a work having to do with conscience?... I know there are some, I don't know if they are among the greatest, though... anti-slavery novels were written out of conscience, even though the phenomena they take up often didn't include the actual exercise of conscience.

Tomás Chuaqui: And what about the vices of democratic individuality, if there are any, where would they be?

George Kateb: Read any novel you want (laughs). They interpret positive individuality, selfexpression, as anything goes, they waste their expressiveness, they become licentious, self-indulgent, slovenly, and everybody must be allowed their ration of such vices. But if they are not working

1 Here Professor Kateb is alluding to a distinction he makes in the book The Inner Ocean (1992, p. 30) between positive, negative and impersonal individuality. Positive individuality is linked to the possibility of abandoning identities and exchanging roles; with experimentation and a passion to work on oneself. Negative individuality is associated with stigmatized or relegated groups who say no to their condition and who claim that each member should be considered individually, not merely as a member of a category-the movement led by Martin Luther King Jr. would be exemplary of this type of individuality. Finally, Kateb describes impersonal individuality in terms of a certain engaged detachment; a kind of observation that could ultimately lead to recognition, if not always to acceptance. 
steadily in the direction of having a vocation, of finding something to do that is worth doing, and doing it as well as they can, then democratic individuality is, if you will -the opportunity is- wasted. It's a harsh thing to say. But I think you would have to say it from the theoretical perspective, while knowing that you are as guilty as everyone else. These things happen. But, you see, it also sensitizes you to an aspiration to be better than you are, in even the most trivial pursuits. There is something straining for expression that is not to be despised: being real, feeling real, feeling in touch, learning from others by exposing yourself, by being an exhibitionist. There's some, often there is some aspiration.

Tomás Chuaqui: Richard Rorty, I think argues at one point that if the cost of living in freedom is having citizens who are not only not admirable, but who are not even worthy of respect, maybe that's just a cost we have to pay for freedom, and that's just too bad (1991). You would, I think, not accept that, or have at least the hope that most people would aspire to be...

George Kateb: ...yes...

Tomás Chuaqui: ...respectable at least, admirable perhaps. And I was wondering if you would -if you accept that characterization- if you would think that one of the aspects of your overall sensibility, one could say, has to do with some sort of perfectionism? Would you accept that term applied to your work?

George Kateb: I don't accept it. And I think I've tried to be careful over the years in saying that perfection is not a worthwhile standard. The idea of perfection holds that you can give a shape to your life that is without serious flaw; that you become like a work of art as a person, and everything you do is, so to speak, artistically complete and perfected. I've never credited that idea. I don't like the idea's endorsement in Nehamas's Nietzsche (1985), and I don't like Nietzsche when he sounds this way. However, I take very seriously Foucault on "care of the self". And especially, not in the book by that title, but in the last three courses of lectures he gave at the Collège de France. If I were young enough, I would undertake some project on those three last courses there: Hermeneutics of the Subject (2005), Government of Self and Other (2011) and Courage of the Truth (2012). This kind of care of the self is not perfectionist! It has nothing to do with wanting to become admirable. It has a lot to do with reconciling yourself to yourself, and reconciling yourself to suffering and death, which must come with age. This care of the self, which I find in some of Foucault's antecedents, but especially Montaigne, I take very seriously. But that's not perfectionism. Rawls has a definition of perfectionism in A Theory of Justice (1999). He explicitly repudiates it on the grounds that this is an impossible standard for people, and it can countenance injustice, what is more, if the perfection of the few requires the subjugation of the many. Cavell uses that word, applies it to Emerson (1990). I again worry that Emerson is not being read quite correctly, because I don't think Emerson thought that activity and the way of living could become art in themselves, deliberately. Emerson has a notion of vocation which I tried to substitute for Cavell's notion of perfectionism as the antithetical idea. You do your work if it's worth doing and do it as well as you can. You take your mind off yourself; you care for yourself by doing your work. That's one part of care for the self. The other part is Foucault's last writings, some of them written under the knowledge of his impending death. These writings have to do, really, with Stoicism, in the capital "S" sense. He takes up Socrates -the stoic, pre-stoic in Socrates- and he takes up Seneca, Epictetus, Plutarch and what attitude they take about suffering and death. His writing is thrilling. This depressing subject Foucault, by the power of his mind, makes, as it were, thrilling, especially if you are old, as I am. He wasn't old, but he was dying. He was 53 or 54. I take that very seriously, but not perfectionism, either in Nehamas's Nietzschean sense, or in Cavell's sense. But I think that Cavell is closer to what I'm thinking than the coldness of Nehamas's Nietzschean self. Imagine becoming a work of art. I mean, this is... what would that mean? Become a dandy, or Dorian Gray? Now, there is a great work on the perils of the self as an artistic creation, The Picture of Dorian Gray (2003), written by a dandy who was also a deep and serious and compassionate moral thinker: Oscar Wilde.

Tomás Chuaqui: How can you detach care of the self from some pursuit, perhaps not of perfection, but of some sort of an ideal that you are aspiring to become?

George Kateb: Right. 
Tomás Chuaqui: Even if it's a personal one.

George Kateb: Good question. If you commit yourself to an ideal, you sacrifice yourself. So it's not perfection of the self to become an instrument of the ideal, as in a way you become an instrument -but that's a harsh word- of whatever it is that defines your vocation.

Tomás Chuaqui: So you give yourself to the project rather than...

George Kateb: Yes! And a synonym for project would be pursuit. But never of happiness, which is a terrible, bogus ideal. To pursue happiness is really appalling as an idea, as in the Declaration of Independence. As Nietzsche said, only the British believe in happiness. (laughs) Or he may have said English, but I was trying to include, you know, the American colony. English! Only the English believe in happiness. It's just a marvelous throwaway line, false, of course. Everybody believes in happiness! Look at Plato and Aristotle, for example, rigorous as they may have been in their definition of happiness.

The pursuit of the project; or the pursuit of the pursuit; or having something to do outside yourself. And if you grow in this pursuit, fine. And if you acquire what Auden calls "the dyer's hand" (1990) by your pursuit, fine too. Your skin turns the color of the dyes you used on the object you are dyeing. You become stained by the work you do. Better that, than not having work to do.

Tomás Chuaqui: Does "becoming who you are" ring a bell?

George Kateb: Yes it does (laughs). It's Pindar, then Emerson, then Nietzsche, right? Emerson says "be what you are", and Nietzsche transforms it into "becoming", which is a subtle- not so subtle, it's a profound difference, and an important one. But, as I tried to say in the Emerson book, be what you are can also be said in the tone of voice "ah, be what you are; don't pretend you're not that, and put up with it and make the best of it". "Realize your potentiality"? Again, that's very ego-centered. It is trying to get your eye off yourself, that I think Emerson, Thoreau and Whitman teach, better than most others who are anti-individualist. Try to engage: this is not that vulgar xenophobic communitarianism.

Tomás Chuaqui: You've argued that constitutional democracies allow for this kind of life for its citizens better than any other regime, I think, and I was wondering to what extent, if I may ask you a sociological question...

George Kateb: ...sure...

Tomás Chuaqui: ...you think this is actually the case, in existing constitutional democracies? Would you argue that potential for this kind of a life has been naturalized better in constitutional democracies, such as the one in the United States or in Western Europe, than in other historical examples?

George Kateb: Let's say... some things have been actualized better, and other things not. I think that the US American culture is more easily appealed to on grounds of conscience, or has become that way, than any other society I'm aware of. Not to deny that, especially in the northern Protestant countries, not the Catholic ones, action out of conscience is a known and respected phenomenon, whether it be Germany or Great Britain. To some lesser extent in France; Doctors without Borders is a French invention. When individuality is in its negative phase, resistance on behalf of others, I think the US has shown itself, after, and because of, Lincoln, to be more capable of it than other societies. And it is the Protestantism in the founding that accounts for it. This is not to deny that the idea of conscience has Catholic sources, Catholic beginnings. Not to deny it at all. But it is martyrdom on behalf of one's faith; that's not what's involved here. It is being a martyr on behalf of morality that I find, that I have found, in the US. It is a minority phenomenon, as abolitionism was even before the civil war. A minority, persecuted minority, but it was, it was not to be denied, and it eventually prevailed through that mysterious man Lincoln, who was anti-abolitionist. And it has engendered various movements of great importance from the point of view of conscience: the rights of blacks; the rights of women; the rights of gays; the rights of disabled people. All minority phenomena, addressing themselves to a persecuted minority. That's the doubleness of it: a few care about the suffering of another few. It's marvelous!

As far as the other stuff, I don't know what to tell you. You cannot encompass the culture of any advanced complicated society, probably no society, no matter how simple. You can't take it all 
in, again it's "The Armful" phenomenon: you think you spotted it all, and then something drops and you stoop to pick it up to incorporate it, and there's something else you lose sight of. I think the amount of love of cruelty in American society is shocking. There is a worship of cruelty in American society. I dare say it exists in every society. But it is given expression in the mass-media in this society to an extent not known elsewhere.

Tomás Chuaqui: The worst vice, according to Judith Shklar...

George Kateb: "Putting cruelty first", quoting Shklar, using Montaigne, and then building up to writing this great essay of hers on cruelty in Ordinary Vices (1985), and then in "The Liberalism of Fear" (1989). Not as great as the chapter on cruelty in Ordinary Vices (1985), because she dismisses rights in "The Liberalism of Fear", thinking that they are the preserve of the few. I mean, she sounds like a -not like a bolshie exactly- but she sounds like a teary social-democrat when she does this, as I told her- (laughs) or I think I did; certainly I did to her ghost, if not to her face.

I don't know what to do with the phenomena, the various phenomena, of mass culture, most advanced in the US. And then when exported they become even worse... even worse. Only the bad things, said the novelist Robert Stone (1985); America exports only its bad things. In Human Dignity (2011), the worry about the baseness of democratic culture... I must say I have it. I must say I cannot help thinking that when the few, the elite, monopolized resources they produced what we still live off. It's a terrible fact; it must be faced. You can't throw it away, but on the other hand, you can't reproduce it morally.

Tomás Chuaqui: This is a sort of a Marcusean worry about mass-culture that you still retain?

George Kateb: I think he is not alone in this! God! There are many American pessimists about the level of American culture. But he does it in a way that's most interesting to Political Theory. Marcuse is saying: You are defending this form of government, in part because of what it makes possible? Look what it's making possible! And much of it is terrible, but not all of it is. He was more surprised than anybody by the youth movement, protesting the war.

Diego Rossello: May I jump in now in this tone of social commentary? How do you react to the figure of Barack Obama in terms of the best and the worst of mass culture and representative democracy? Is it possible to find any traces of the democratic individuality that you foster in the figure of Obama? Or is it just the same in a different package?

George Kateb: Two things. First, people in the millions thought nothing -nothing!- could be worse than George W. Bush. And they would vote for any Democrat. Two, Obama is great above all because he dared to run and then he won. As a president it's too soon to say, some things he has done I admire. Other things, I do not admire. He has retained some of the worst parts of the Bush administration: infringement on liberty and freedom from surveillance. He claims to have abolished torture: well, I hope he has. He is a good president. But his greatness resides in the courage of running, knowing that he could be assassinated at any time. He still knows it. He gets five times the number of threats that his predecessor did. There are many people who would love to kill him, or at least see him dead. It takes tremendous courage, on the part of his wife as well, to do this. He knows what happened to JFK, and Robert Kennedy, and Martin Luther King. Not only Martin Luther King as a black man. John Kennedy: the hatred of John Kennedy had to do with Kennedy's (even though tepid) commitment to civil rights; and Robert Kennedy, his murder had to do with his more ardent embrace of civil rights. Racism is deep in American society. It is worse than its greed, its racism. However, it turns out that the majority said "we'll elect a black man". Twice! That's amazing! The first time even North Carolina voted for him, and Indiana, which is worse (laughs), believe me, it is worse than North Carolina. So Obama is a phenomenon. By God, I hope he survives his second term. Literally, survives it. And then we'll see what he achieved. I mean, he is, at the very least, a good president. He has faced terrible problems. And the nature of his opposition is disgusting. I mean the Tea Party, racist opposition. Not the other kinds of opposition. Undeniably, the national -not the deficits- but the national debt, I think is a genuine problem. We pay a lot of interest, the US does. A lot of its budget goes to making sure the interest -just the interest!- of the national debt is paid. What do you say?

Diego Rossello: I think I agree. I was here when everything started. 
George Kateb: When Bush was president?

Diego Rossello: Yes, at the end of the Bush presidency and the beginning of Obama's. I was living in Illinois, so I saw it from the beginning. When Obama won, I was in Paris, at a gathering of the Democratic Party, and I saw French black people crying in front of the TV.

George Kateb: But they were black, African?

Diego Rossello: Yes... Afro-French.

George Kateb: No whites, crying?

Diego Rossello: There were whites, and they were very happy. But those tears I remember the most. Because I thought: what connects them to Barack Obama? They speak French, they happen to be black, and they are in Paris right now. And they saw the rise of Obama as a way... of vindication, finally.

George Kateb: Right. Somebody did not despise them.

Diego Rossello: Yes.

George Kateb: Yes. It turned out to be the majority of voters in the US, of all things. Yes, right.

Tomás Chuaqui: How much of that would you attribute to a sort of reaction to the excesses of the Bush administration?

George Kateb: Yes, a lot. I mean the relief of getting rid of George W. Bush...was tremendous. There was an incident: Justice Ruth Ginsburg ${ }^{2}$ came to do a lecture here, when Bush was still president. And she was received in Richardson, this enormous hall that holds five or six hundred people, something like that. The applause would not stop when she was introduced. Because she stood for something antithetical to the Bush administration -this is when Bush was president, as I said. It was an amazing moment. I've never heard such prolonged applause, except one other time, for Pierre Boulez conducting Mahler's Third Symphony at Carnegie Hall: he received fifteen minutes of applause. Apparently such ovations have become more common. Ginsburg didn't receive fifteen minutes, but she must have received... three minutes? four or five minutes? That's a very, very long time.

Tomás Chuaqui: Before she actually said anything.

George Kateb: Yes! Absolutely, yes... right...

\section{SESSION 2}

The second meeting began with no opening question from the interviewers. Professor Kateb initiated the session by reflecting upon our conversation the day before, and directed our attention to his book Patriotism and Other Mistakes. The following dialogue ensued.

George Kateb: My sense is that if you want to understand what I was thinking after I published The Inner Ocean (1994) and the book on Emerson (2002) in the mid-90s you would go to the "Introduction" and the first five essays of Patriotism and Other Mistakes (2008). That is practical politics theoretically thought about and presented. And it includes an essay on patriotism as a mistake, pluralism as a mistake, on the surveillance state, on the attacks on the Constitution that the war-making state inflicts, and an essay on the origins of the invasion of Iraq. The last one is called "A Life of Fear", which I think got me into some trouble, because I blame most of it on the Israel lobby, and say so. The partisan defense of privilege from the Republican party -of both parties; both parties of course defend privilege, but the Republicans more intensely sofound in these Israeli connections something useful to their own purposes, and Israel found in the Republicans, the Bush administration, something useful to their purposes. So there is mutual use, mutual exploitation, with terrible damage to the Constitution and to the course of American 
policy. You can't blame it all on Bush; Clinton introduced the sanctions against Iraq, which apparently cost half a million Iraqi lives. Which Madeleine Albright defended, after she was out of office, by saying... "it was worth it". That means killing half a million innocent civilians. What the "it" is, has never been really clear. And it is interesting that Reagan opposed Thatcher on the Falklands, and he and his successor, Bush (H.W.), was accused of being wobbly by Mrs. Thatcher on the first Iraq war involving Kuwait. So these things are very complex as I say in this article, "A Life of Fear". This article is also... it's meta-theoretical, it's about how you understand opaque political phenomena, and whether a conspiracy theory is adequate to understanding things. And I say, yes it is, often. What is conspiracy? It is simply -usually- an unavowed collaboration, for purposes that may not bear examination by moral or legal standards. It needn't be sinister, but it remains largely unavowed, out of moral or political embarrassment. As La Rochefoucauld said, "hypocrisy is the tribute that vice pays to virtue". So, I say, if people don't think I have practical political views it's because they are not aware of these essays -the Introduction, which is, again, a theoretical introduction, and the next five essays, in the Patriotism and Other Mistakes (2008) collection, published by Yale in 2006- some of which appeared in Social Research, a good journal that not many people in political theory read.

Diego Rossello: I would like to jump in, precisely, on those first two essays. If I remember correctly you make a critique of patriotism in the context of the critique of any kind of group identity theory. And in the course of making that argument, you engage in a criticism of Richard Rorty's tendency to be more open to group identities than you are. And now I'm thinking that perhaps Richard Rorty was also more open to patriotic rhetoric...

George Kateb: He wrote a whole book about patriotism: Achieving our Country (1999)...

Diego Rossello: So, what do you think are the main differences between your position and Rorty's on the issue of group identity and patriotism?

George Kateb: I think there are differences on this matter of group identity, and the instrumental use of patriotism, which is what Rorty engages in; he is simply too clearheaded to think that there is something profoundly true and right in any patriotic feeling. But Achieving our Country is a sermon to the left, saying: you cannot be antipatriotic, you must support American foreign policy, you must inculcate loyal sentiments, if you think you are going to be able to reform -in a left wing direction-American society. The failure of the left often is that it is not nationalist or patriotic. So he wrote this book which I think is the one book he had any reason not to be especially proud of. The book on contingency (1989) is marvelous and the first one, Philosophy and the Mirror of Nature (2009), wonderful. Neither book is probably something I can agree with on all particulars, but in many respects these are two exhilarating books that are instructive, and worthy of critique, and if need be, of demolition. But they certainly instruct you as they go along. Whereas Achieving Our Country is a lay sermon; it is meant to be an essay in persuasion. I have no doubt that he would give the benefit to those who are patriotic over those who are skeptical about patriotism. He may have taken some pride in his American citizenship. But insofar as he did that, and related things, he ceased being philosophical, it seems to me. And he became, not a propagandist exactly, but someone arguing below his best level. Do you think well of that book?

Diego Rossello: Well it was different; I read that book in South America. And we were receiving perhaps not the best products of the so-called cultural left that he was writing against. So it seemed like a good corrective, to remind us that... if we were leftists, we were supposed to be engaged in everyday politics and not only about, you know, complex genealogies of the latest Hollywood movie. That sounded appealing...

George Kateb: Wow... Cultural criticism had replaced political criticism, is that right? It's still true to some extent.

Diego Rossello: Yes. And I think perhaps you would be closer to Rorty in that respect, if that is the critique of this cultural left, of the postmodern cultural left.

George Kateb: Though it is much more interesting to read cultural critique than political critique, because political critique involves you in a fairly limited range of considerations, whereas cultural critique is the criticism of everything existing. Is that the title Marx gave to the letter to his father? 
(1978). Yes... which is to say, cultural critique does not achieve what it aims to: change society. But it certainly, at its best, as sometimes in, say, Zizek, it really wakes you up. But it's not a substitute for political critique or, much less, for political action. So I can understand how, in, you said, South America, you found this a bracing challenge to redirect your intellectual energy. Is that right? Good. You see, that's the point about not only great books, but even good ones, or not so good, but nevertheless, pretty good, as with Achieving Our Country (1999). They have different effects on different audiences, and you never know what unforeseen and perhaps unintended effect will result. The influence of a readable book stretches out indefinitely and will affect different people in different ways, in different periods of time as well, not just in different places. That is a very interesting account that you just gave us.

Diego Rossello: Again, on this topic of patriotism and Rorty: yesterday you mentioned that you thought John Dewey did not have a very significant intellectual influence on you; or that you didn't identify with Dewey's thought. Yet it seems to me that you share much of the canon with Rorty. I think you would agree on Emerson, on Whitman, on Thoreau. Perhaps you would agree with him on William James...

George Kateb: Yes...

Diego Rossello: ... but then I see that you depart from him very strongly in the case of Dewey. Does patriotism, or Dewey's engagement as an intellectual have something to do with it?

George Kateb: Dewey is a very large phenomenon. There are many books and articles about him, and, again, he was a thinker whose influence radiated out to all sorts of audiences and continues to radiate, though perhaps a little less so over time. I object to Dewey's clumsy style; I don't find him interesting to read: one; two: his depression-era books in which the engineer emerges as a model or hero, these books strike me as, again, instructive, but... not acceptable; three: his effort to socialize individualism, as in the book with the word individualism in the title, is it "New and Old" or something like that? (2009). And sometimes his tribute to Emerson shows that he is actually betraying Emerson. His essay on Emerson is not a very interesting one; he is deradicalizing the Emersonian contribution by, first of all, setting limits on the possibilities of being individual, by emphasizing the impact of the society on the person. And second, taking away the radical aspiration in the Emersonian tradition (Emerson, Thoreau, Whitman, and whatever heirs they might have) in which the image of the person that you can distill from Emerson, and Thoreau, and Whitman is obliterated by Dewey. What is that image of the person? It is someone who refuses to be had, to use a slang expression, when you are being taken over by something, some pressure, and deceived. The Emersonian tradition posits the possibility -it's a Cartesian possibility, more than anything else- that I can come into possession of a sense of myself as being not merely the sum of everything that has happened to me. I can take a stand against my own susceptibility and seducibility, and I can say "yes" on my own terms, to some extent, and "no" when I think "no" has to be said. And I can, lastly, entertain the possibility of being receptive to an indefinite number of phenomena, some of which distress me, some of which appall me. But my effort always is, not to take received opinion as my own, and try to understand what is going on when I seem to be upset by something that's happening, or unusually attentive to something that's happening which is better than people say it is, and so on, indefinitely. The independence of response, made possible by a cultivated independence of mind, though it may be exemplified by Dewey, is not taught by Dewey. And you cannot think that you are being true to Emerson and his heirs; you cannot even say you are an heir of Emerson -as people have said that Dewey was, and I don't think he would have denied it- you can't say what Dewey says and still be an heir of Emerson, or true to Emerson. Now, one; two, Dewey wrote some things that are of lasting value. I think his best book -though I must also say, in honesty, I've not read some of the most famous John Dewey books- but, of the books and pieces that I have read, I found Art as Experience (2009) to be the best, and a really wonderful, though heterogeneous, book. It is what Henry James said of the novels of Tolstoy: they are loose and baggy monsters. There's more there than can be assimilated by some strict aesthetically appropriate discipline. But that's ok, it is a wonderful book: Art as Experience (2009). The other one is his Theory of Valuation (2008). He is the first and best to theorize the absolute dependence of ends on means, and means on ends. In fact he gives priority 
to means, and it is very much what Gandhi preaches. Not because he read Dewey -Dewey's essay, Theory of Valuation (2008), is late 30s. Gandhi is following Thoreau, following Tolstoy, but Gandhi says: never mind the ends, think about the means first, think about the means as a way of life. Think about a way of life committing you to ethical action, and constraining you in your action. This is in Gandhi, it is not exactly that way in Dewey, but the theory of valuation is an abstract theory, and it is saying: no consideration of ends until you've considered the means. Don't fetishize the means, but if something exacts, speculatively, some tremendous cost, you better think again. That's an easy point, and he deals with it in his debate with Trotsky about "Their Morals and Ours" (2000) (this is Trotsky's title, I believe, for his answer to Dewey). It is not only that ends can be costly; it is not as simple as that. Of course, that's true, it's an invaluable lesson, usually forgotten, but that's just part of it. The larger part, theoretically if not practically, in John Dewey's Theory of Valuation is that you just can't separate means and ends as easily as you think you can. The means that you employ will help to determine the ends, the provisional ends that you achieve might then force you to reconsider your attitude towards your means, and there is a to-ing and fro-ing, there is a give and take between means and ends. This is a great moral essay that Dewey wrote, and Art as Experience is a great book about the human condition. These two are enough for me to enlist Dewey in the ranks of thinkers worth taking seriously. But, for the rest I have either ignorance, which is modest, or ignorance which is dogmatic and arrogant and stupid. I partake of both tendencies (laughs). So look, Diego, if you want to go on reading Dewey and making something of him, I would not discourage you. But he's not Emerson, he's not an heir of Emerson, he's something else. William James is an heir of Emerson.

Diego Rossello: Ok, that's an important distinction, and I suspected you would make, at some point, that distinction between James and Dewey. But you said something that sounds very strong: that Dewey did not teach independence of mind. And that brings me to another thing that we wanted to ask you. There are many schools in political theory, there are many "isms". There's Pragmatism, there's Republicanism, there's the Cambridge School...

\section{George Kateb: Yes.}

Diego Rossello: ...but there's no such a thing as "American Democratic Existentialism".

\section{George Kateb: Ok.}

Diego Rossello: You have been teaching for many years, you have had many advisees... George Kateb: Yes.

Diego Rossello: So I was thinking, why didn't you develop a school? And if that is a problem for you. Or, to put it differently, how do you conceive of the relation between you, as an advisor, and your former advisees? Do you resist this kind of "school" or even group-identity when you take on the advisor-advisee relationship?

George Kateb: Right. Well, your question has a generous premise. The generous premise is that I could be capable of forming a school if I chose to (laughs). And that I doubt very seriously. Really I do, and this is not just mock modesty which, as Aquinas reminds us, is also a sin. It is an effort to be accurate about oneself. First. Second, the first graduate seminar I taught at Princeton in the fall of 1987 devoted itself, not exclusively, but for the most part, to the theory of individualism. And I assigned some Emerson, some Thoreau, and some Whitman. I felt that students were accommodating me by doing their work, and I did not want that to happen again: merely being accommodated; being humored; being indulged. I didn't think that they were interested especially. Many of them, thanks to the influence of Sheldon Wolin, were on the left. And my writings and teaching on this subject were certainly not on any left that Wolin and his pupils would recognize. But, the seminar went very nicely, and there were some fine students in it who did excellent work. But I had the sense that this was not something that I could go on with. Thereafter I, maybe once more, years later, taught something by Emerson and something, especially, by Thoreau: the essay "Civil Disobedience" (2006) is a sure winner; it is a great essay and it deserves the enthusiastic response that it generally receives.

So, there is no school. I certainly had never tried to enlist students as a kind of following, in this direction. It is true that in recent years the University of Kentucky Press, under the instigation 
Patrick Deneen, who taught political theory here, then went to Georgetown, and is now at Notre Dame, has commissioned Political Companions to Emerson, and then to Thoreau, and then to Whitman; and one on Melville, related, is coming out soon (2013; 2014 and 2014). I am delighted by the amount of interest in these three thinkers on the part of young political theorists, and I'm pleased that these Companions exist. But it is not a school. It is still a rather eccentric choice of emphasis. It's not going to help you get a job very much if you say you are interested in Emerson and the Emersonian tradition. A really brilliant political theory student here named Alex Zakaras wrote his dissertation on Emerson and Mill. I was not on his committee because I had already retired, but he did take courses with me. The book was published by Oxford, and is called Individuality and Mass Democracy: Mill, Emerson, and the Burdens of Citizenship (2010). It is a wonderful book. So there are things that sprout here and there. You know, it would be against Emerson to have a school of Emerson. Though I sometimes use the phrase "Emersonian", it is only... it's almost a kind of active spite to those who think that he never had influence over anyone who counted. There are Emersonians, but it is better to speak of Emerson and his heirs, of those who read Emerson devotedly, like Thoreau and Whitman, and then developed on their own.

The last point is this, and it's the most important. Philosophers should not be like fish, they should not travel in schools. The English expression, you know, "schools of fish;" that's what groups of fish are called. My general thought -and it is an Emersonian thought- is that every student will have a certain direction of his or her own; certain strengths, as well as accompanying weaknesses. And they should pursue their own interest, not my interest. And I don't want them to study anything and work hard, as our graduate students do, and then go through the ordeal of finding a subject and writing a dissertation, and then continuing with their work thereafter, I don't want them to do all that at the behest of any teacher. And here it has not been the case. It was not the case when Tomás was a graduate student. We on the faculty were all called liberal, but this was a Wolinite perspective on his successors (laughs). I mean, there were Amy Gutmann, Paul Sigmund, Alan Ryan and myself, and Maurizio Viroli and Elizabeth Kiss as a junior member; there's no party line here. There is no school. And we would, each of us, direct dissertations on subjects that had nothing to do with our interest, even though we were interested in what the student was writing. I understand that in the European system and in Latin America, and not only there but probably elsewhere, and because of the influence of Europe in Latin America, graduate students may believe that they must enlist themselves in a school or perish. That is not the Princeton way; it is not the Harvard way. Look at the diversity of political theorists in Harvard, leaving our school here aside. They don't agree on anything. And the strain sometimes shows in departmental disagreement. But Richard Tuck, and Nancy Rosenblum, and Harvey Mansfield, and Michael Sandel, they just say "pick something that interests you and I will work with you". The same is true at Duke, even though Peter Euben has retired. I believe it's true at the University of Chicago; they have great diversity there, of approach. It's no longer a Straussian department. Only Tarcov is, and he is the most moderate of intelligent human beings. And he's only part-time in the department in any case. There's no school at Berkeley; Wendy Brown is an eminent figure but I don't think she seeks converts. Northwestern, your school, Diego? I don't think that is a school either and it is not meant to be. I think that teachers like Mary Dietz, and Bonnie Honig, and James Farr all say "go ahead; work in what interests you and I'll work with you". I think that's the right attitude.

Diego Rossello: What about the Rawlsian school? We were meaning to ask you about your relationship with Rawls's thought. It seems to me, there's at least one strong difference that I can identify quickly for the purposes of this interview, which is the existential emphasis of your take on democracy, and even justice; and perhaps the more analytical or formal -I don't want to be unfair- emphasis of Rawls's take on democracy and justice. What do you think of Rawls's influence on the language, the vocabulary, and the style of democratic theory?

George Kateb: It's a very good question. Really, a very good question. And I've thought about it, though not exactly as you stated it, but I'm glad to hear your statement of it. Someone told me that his inquiry revealed that I was the first Poli Sci based political theorist in the country to cite John Rawls, and this in an essay on Rousseau which I published, I believe, in 1961, in Political Science Quarterly (1961). It was on Rousseau; it's called "Aspects of Rousseau's Political Thought", and in 
it I refer to Rawls's great essay "Justice as Fairness" (1958) which appeared, I think, in 1955 or 56 or late 50s... something like that. And I thought that Rawls's essay cast an excellent light on Rousseau, though, to be sure, it was a light affected partly by Rawls's immersion in Kant. Still Rawls had a tremendous interest in Rousseau; you can tell from his Lectures on the History of Political Philosophy (2008). So from the start, and thanks to my friends, I started reading Rawls. I read his other essays, "Two Concepts of Rules" (1991); the ideal observer, that essay on the right moral point of view; these are brilliant, magnificent essays. And then when A Theory of Justice came out in 1971, I made sure to read it all. Since that time I have read, I believe, almost all the essays in Political Liberalism (1993), even the three on Kant's constructivism, the hardest writing in the XX century. And it's just way, way, way too -everybody says- that it's just too hard, but doesn't mean it isn't good. And then... and then, the big letdown: The Law of Peoples (2001). Which I think, again, is an instructive book, but he abandons his theory. What is A Theory of Justice? It is a theory of the legitimacy of institutions, and in The Law of Peoples he makes this untenable distinction between a decent society and a just one, or whatever... a "good-enough" society, and accords it equal legitimacy under international law. Well, under international law you have to respect every state as a state as such. But the moral element seems to drop out, or if it is retained, it seems to me to be a betrayal of Rawls's theory of justice. I have not kept up with two things: the revision of $A$ Theory of Justice (1999), and Justice as Fairness: A Restatement (2001). I've not read these books. So, I am not a complete Rawlsian, though I think I was, for a while, a nearly complete Rawlsian, out of tremendous respect for his intellect. One. Two: have I benefited from Rawls? Yes, a great deal. I think, for example, that the distinction between a pure and a perfect procedure, from A Theory of Justice, is invaluable along Dewey's lines in Theory of Valuation. Have I learned something about the requirements of justice from Rawls? Absolutely. Have I learned from A Theory of Justice, especially, how to criticize certain ideas? Absolutely, including perfectionism, but also utilitarianism, most importantly. Where do I start worrying? First, concerning the thought experiment, in itself; second, the difference principle; and third, talents as social assets. Three points in A Theory of Justice which prevent me from saying I am a Rawlsian, despite learning from him. The thought experiment finally reduces to rational choice and not a will to justice. You're stripped down in this thought experiment, and the only person who has a will to justice is the person who sets up the experiment: John Rawls. And behind the veil of ignorance, what do you choose? You choose prudentially, you follow the maximin strategy; you want to minimize your losses, first, and then maximize your gains. That's self-regarding, that's not a will to justice. There is some worm in the bowels of that theory, if I've understood it correctly. Second, the difference principle justifies inequality only on the grounds that inequality redounds to the benefit of the least well-off. I have thought, and still think, that the demands of certain practices in life require inequality, and these other demands can be justified apart from justice, and they sometimes conflict with justice. The demand that interests me most -and it comes out more starkly in the book on human dignitythe claim that concerns me most and that I cherish most is the claim of high culture, which seems to require privilege. The greatest things have been done not in egalitarian or just societies, but in societies that were inegalitarian, and even sometimes oppressive. The arts, some of the science, the literature, the philosophy, practices of life, almost all arose from inegalitarian societies. Even the achievements of Athens -democratic, yes, but the citizens were a small minority in a large city. Third: talents as assets, right? This makes me into a mere instrument of society. It's a terrible thought! And when Thomas Nagel and Liam Murphy wrote this book on "your money is not your own" (I forget its title) (2004) -this is Nagel, one of the leading, perhaps the leading living American Anglophone philosopher! I read one essay. Your money is not your own, it's owned by... I don't know, they don't even say. The State? Society? It's not clear. And therefore, since it isn't your own, you can be taxed at any rate that benefits the common good. I find this, again, an abhorrent idea. I believe in the Lockean principle of self-ownership. It's part of democratic individuality, it's part of the foundation, or part of the basis, of democratic individuality. It is a Lockean idea, and the Lockean idea is not exhausted by Locke's theory of property. I own myself; I'm not to be owned. I am not the well paid servant of society. In some sense I exist before society, to the extent, following Descartes, that I can stand back from everything, push back everything that has happened to me, and say "I"... "I think!" Rawls seems to -especially more and more with time, and more and more as the book proceeds- to become (laughs) too much like John Dewey. 
Diego Rossello: That relationship between Rawls and John Dewey was unexpected, to say the least. But it is very suggestive. I'm tempted to enter directly into Human Dignity.

George Kateb: Go ahead.

Diego Rossello: Given the way you are putting it, I'm seeing how Human Dignity can work very well as a response to A Theory of Justice, or to the work of Rawls.

George Kateb: It was in my mind as I wrote, but obviously it wasn't the only thing in my mind. Certain things that worried me about Rawls found their way into my thinking about human dignity. But by far -certainly in the first half of the book- the worst enemy of the book is... the worst of my enemies, if you will... is the principle of utility.

Diego Rossello: I see. I think, perhaps, also your disagreement with Rawls is reflected in the distinction you established in Human Dignity between the moral and the existential dimensions of human rights. I assume that if he were to justify human rights, Rawls would do so on Kantian, moral -and not on existential- grounds.

George Kateb: He does use the term "human dignity" somewhere far along in A Theory of Justice. And it is a couple of pages, and he accepts it, but I think he indicates that human dignity is not a foundational value. I think he says something like that. Or if he doesn't put it quite that way, explicitly, the notion plays almost no role in the book. Whether Rawls, in some sense, worried about human dignity, I would never deny: he did not want people treated like rubbish, or disregarded, or used merely instrumentally. That's why the business of talents as assets is such a sudden, I think, damaging notion found in Rawls, and not fully prepared for, and certainly inconsistent with the general tendency of the book. So, you were saying, moral and existential, the two aspects of the defense of rights. If you don't want to use the word "existential", you could always simply substitute for it the word "dignity", and use it as an adjective as well as a noun; so that there is a moral component to the defense of human rights, and a dignity component. They are conceptually separable: that, I would insist on. And they usually cooperate with each other, but sometimes they don't. I realized, after finishing the book, that I tended to give the dignity component -perhaps; I'm not even sure if that is what I did- the upper hand. Even as I denied that there is anything more important than morality, I seem to affirm that there is. And some, even fourth rate Derridean would immediately, if they took the trouble, pounce on this (laughs). You noticed that I didn't say a Derridean, I said a fourth rate one, and clearly that does not apply to you. Would you make the Derridean point against Human Dignity? That there is an unstable relation between me and the comparative ranking of morality and dignity?

Diego Rossello: I think I would make other Derridean arguments, not that one. I think that in your vocabulary, in the intensity of your writing, you tend to favor the existential dimension over the moral. And I think it is true, as you say, that they should cooperate. But in your style of writing, and if we read your prior work, it's fairly obvious that the invitation is for us to explore more deeply the existential, the possible existential justifications for human rights. At least, that's how I read it. But now that you invoke my Derridean background...

George Kateb: Of course.

Diego Rossello: My Derridean, I don't know how to call it, suspicion, is that in order to build a notion of human dignity, your argument tends to stress a break, needs to stress a break with nature.

George Kateb: Yes.

Diego Rossello: That's what makes us different.

George Kateb: Absolutely.

Diego Rossello: And what makes us dignified, or gives us the possibility of being dignified and have access to human rights.

George Kateb: Yes.

Diego Rossello: But then you make another argument, which I found unexpected and very interesting. That is that we can only honor that dignity if we assume that we have to care for nature, or be the stewards of nature. We've been discussing this for a couple of months now in a 
graduate seminar. And, you know, there are critical discourses like animal studies and biopolitics that tend to be very wary about investing too much in dignifying the human because they assume, perhaps wrongly, perhaps not, that we can be devaluing other forms of life at the very moment that we invest too much in human dignity. Would you see this as a risk?

George Kateb: Yes, I do. And I've tried, though not hard enough, to warn against any arrogance or snobbery that might result from emphasizing the distinction between humanity and the other species. I'm aware of it, I worry about it, but it is where I feel I must begin in order to prepare the way for the rest of the argument. But I also think it is true. I do believe that humanity is distinct from all other species, and it is, of course, a biological fact, given the makeup, the composition of the human body, that we can do things that no other species on Earth can do. Howsoever you may want to take into account, and I'm willing to do so, the capacities of the Neanderthal group. (I don't even know whether it was a species.) There isn't yet a general agreement on the faculties of the Neanderthals, but they come closest. The biggest question is, could they use language? Well, if they didn't then they are not Homo-Sapiens, though they should not have been exterminated. If I had to guess I would say that despite some intermarriage, apparently, they couldn't keep up with humanity and humanity didn't want to share the Earth with them. Why not? Because they weren't human enough. That doesn't lead to extermination, theoretically, but, I don't know. You treat them like animals, and that's sometimes good and sometimes bad. I would insist that language makes the difference, and that language signifies a break with nature, that this conversation we are now having is not a biological phenomenon, and though made possible by our biological equipment, it is not reducible to biological activity; it's not metabolic, it's not a natural process, it's an unnatural process. We speak in sentences to each other, we understand each other; we say sentences we have not rehearsed, or memorized. We engage in creation which is unpredictable. We are constantly changing what is around us, and inside us. I don't think these are reducible to any biological or physical science. That's the human difference. Obviously you're right, it has something to do with the theory of rights, undeniably. And I try to suggest that it casts back some further light, in addition to morality, on the basis for human rights. But it also then looks forward to human stature as exemplified by the human species vis-a-vis other species, and also looks forward to, in Fichte's phrase, "the vocation of man", "the vocation of humanity". The vocation of humanity now is to preserve nature for its own sake, not only for the sake of humanity. There's something perhaps latently Christian in the idea that the highest attainment of the human being is to be magnanimous. Magnanimity might be, then, the supreme existential value, apart from any religion. It's a Nietzschean thought as well, but he didn't send it in this direction. Is it aristocratic? No, because I don't want the condescension of noblesse oblige. It must be magnanimity. Who teaches magnanimity? Treating people better than you've been treated, that's the golden rule. It is the great teaching in the Gospel of Luke. It's not loving another as you love yourself, I don't accept that formulation. You're not supposed to love yourself at all, anyway. But in the parable of the good Samaritan, it is the casual yet earnest way in which a passerby treats someone in a manner that the person who is receiving help, would not think of following in regard to others. So, in relation to nature, and after all the ravaging of nature that humanity has done, the time has come to see the "vocation of man" as not merely to make amends to nature, and not only to preserve nature for the uses that it can bestow on humanity. But, out of wonder that these things exist. Things that do not wonder at themselves. "The vocation of man" is, really, the fulfillment of the moral intellect. It has to be both morality and... or if not, the relation to nature may not be a moral relation... except, no... let me withdraw that phrase. Stewardship of nature is not a moral idea. It is some other kind of idea. Call it existential. We should associate our dignity, inextricably, with our stewardship of nature for the sake of nature, for wondrous nature, and out of gratitude for being able to be raised in wonder by that which is incapable of reciprocating our gratitude or wondering at itself. The brightest chimp does not find wonder in the fact that earthworms exist. Humanity can wonder at the existence of whatever is. Now, there are many terrible things that also exist, and the wonder always has to be somewhat mottled, modified by the terrible viruses that exist and the ravages of nature. Nature is not benign, but it is not malignant. It is innocent. What happens, happens. You can't condemn a flood for immoral malignity; it is a flood. It's innocent. It is not guilty or innocent, it is what it is. It is water, the indispensable element, 
rampaging, rampaging not out of malice but that's what it does in certain conditions. You must take precautions, but the point is to preserve as much of nature as... I keep using the phrase "as possible", which is meant to take into account the harm that nature unwittingly sometimes inflicts on human beings, through disease and natural cataclysms. I also say it's possible that we are the only mind in the universe, in this vast expanse of time and space. It's possible. We talked about this yesterday; we referred to it in passing. I mean, human capacity simply seems to me to be beyond compare. I know other creatures can hear better than we do, or see better than we do, birds can fly and we can't fly unaided. But it is the comprehensiveness of human faculties and talents... and yet they cannot result in the deification of humanity. Man is not a god, though capable of doing what has traditionally been attributed to God. Some of the things, anyway. But that is poisonous; it's a poisonous thought that we are godlike. We have to adjust the terms of praise of humanity, and of human achievements, in order to avoid arrogance and snobbery and instead submit to the discipline required to be the steward of nature.

Do you find any entry for a Derridean point? For example, does the end of the book not know what the beginning of the book says? Or am I undercutting myself as I go along? Or is there a continuous instability in the argument? Or do I ever forget what I've said? These are all Derridean strategies of interpretation. Do I represent him correctly?

Or am I simply substituting De Man for Derrida? (laughs). Which is quite possible for me to do because I knew Paul De Man, and admired him enormously and I've read a lot of him. I read a fair amount of Derrida as well. I just don't find him easy enough to understand. I think he is harder than he has to be. Unlike Heidegger, who is only as hard as he has to be. Derrida is harder than he has to be. He doesn't take enough care with his writing. He couldn't write as much as he has, and have taken sufficient care. I read his first nine books and then I gave up. I stopped with the book Of Spirit: Heidegger and the Question (1989). Do you know this book? It's a little book on why Heidegger did not use but should have used the Old Testament to illustrate his theory of Being. Ok, Derrida's special pleading, it's a moderately interesting book. It's at least short. But I gave up after (laughs), I think it was, number 8 or 9 . I learned from him, believe me. Margins of Philosophy (1984) is an impressive book, I think. There are some things in Different... What's one of the first books? Difference and...

Diego Rossello: Writing and Difference (2001)?

George Kateb: There you go, right. So that's a very instructive book. But he wrote too much and it's too hard. You have to be Heidegger to write as much as Heidegger wrote. And perhaps Derrida wrote even more. But Heidegger took care with every sentence he wrote. Not Derrida. Still, there are valuable things in Derrida and I just tried a simplified way of giving you, giving us, three or four or five strategies. And if you want to make a Derridean critique of the book on human dignity, maybe some of those strategies would be useful. But, do you have a specific critique of the book as a whole that you'd like to make whether as Derridean or not?

Diego Rossello: I think there's a tension that I believe you are aware of, between investing existential intensity in the dignifying of the human being and, at the same time, trying to curb the arrogance that may come out of this investment.

George Kateb: It can't be done?

Diego Rossello: I think you make a very, very strong effort...

George Kateb: Oh my God! (laughs) What a wonderful put-down. What a wonderful put-down. It shows that you are a very good teacher (laughs).

Diego Rossello: Oh my God... the interview ends here I think... (laughs)

George Kateb: Not at all, not at all. If you think the dignity book is a failure... or if that's not a word you would want to use. If it doesn't succeed as much as you would like it to, you should say so.

Diego Rossello: What I think is that you keep bringing Heidegger into the discussion. And for me the argument of Human Dignity resonates with Heidegger's notion of Dasein being the shepherd of Being.

George Kateb: That's the word he uses. In fact, I cite it, I think. 
Diego Rossello: Yes. Perhaps the vocabulary differs -I don't know if Heidegger would have thought of the "dignity" of the Dasein; he doesn't use that word-...

George Kateb: No, he does not.

Diego Rossello: ...but the kind of relationship between Dasein and what is seems to me to resonate in the argument you're making.

George Kateb: Yes.

Diego Rossello: He would use the notion of "care". You also use that notion and you introduce the notion of "stewardship", which made us think a lot about what exactly you mean by it. It's not a very common, I think, word to use in political theory. And so, I was wondering if you actually see yourself as following up on Heidegger's notion of "care", which also calls back to the existential dimension of the human being, and its rights, and its dignity in the book.

George Kateb: Yes. Yes... I've certainly been affected, influenced by Heidegger, and I've tried to read as much Heidegger as I could, and I've read a fair amount though hardly everything. I mean, his complete works would fill a shelf the length of this table. I find him continuously instructive and rewarding. He is sometimes, for me, too hard to understand but I blame myself and not him. There are two books by him that -in addition to Being and Time (2010)- really bowl me over. There are two books, especially on these things, that mattered to me and the first one in my own chronology -was What is Called Thinking? (1976), which I think I read before I read the second book that has mattered a great deal to me, and that is Introduction to Metaphysics (2000). Especially the idea of "thinking as thanking" has to do with the notion of wonder, and the way in which simply taking thought should arouse wonder. And taking thought not by subscribing to any doctrine, but simply. Perhaps he finds some help, at least, in the pre-Socratics, though he is critical even of them. There is a world, perhaps there need not have been; there is no necessity for it. There is a world. There is also our world, our earth, and our world is in the universe. There is the universe. There needn't have been any of this. I needn't exist. That's why Rorty made so much of contingency. His essay, by the way, on Heidegger and pragmatism -forget about pragmatismthe discussion of Heidegger in that essay is marvelous (1991). There is inexhaustible cause for wonder when very few facts are contemplated: there is a world; there is a universe; there are creatures in it; there are other people in it; and there is myself. It is all a matter of, who knows what? Say, when you think -take thought- you'll be thankful that there is a world, for all its he doesn't say this; I would add- for all its horror. But then, this argument is supplemented by Introduction to Metaphysics (2000).

Delivered as a lecture in 1935, it takes up the Leibniz question: why is there something rather than nothing? I believe that this book has been misread by most of its readers. The aim of this book is to deny the legitimacy of Leibniz's question. Do not ask "why is there something rather than nothing?", because every answer you give will be fallacious. For example, there is a "maker;" there is a reason for things... So he takes Leibniz's question away from Leibniz, and says -but not in so many words- "stop asking the question"! And simply -now let us go back to thinking as thanking- let us feel wonder that there is a world. Don't ask why, because you posit a "maker" -or a reason- in the very question "why?". There's no answer to why. It just is! And the word he uses about humanity, "it is there", Da-sein, being-there, that's true of everything. It is just there. And isn't that cause for wonder? If it isn't, then nothing is! It is, I guess, the completion of Heidegger's thought. Is this in my book, Human Dignity? Yes. And I believe I first came across it in Hannah Arendt not in Heidegger. And it is thanks to Hannah Arendt that I began reading Heidegger. She misrepresents him on this point. She does not see that Heidegger thinks that Leibniz's question is illegitimate.

Tomás Chuaqui: I wanted to go back to the distinction, or the relationship, between moral values and -I don't know if to call them this- existential values.

George Kateb: Ok.

Tomás Chuaqui: I think you refer to existential values as values of identity.

George Kateb: That's correct. 
Tomás Chuaqui: I'm sure that this is not what you do, or even mean to do, but I was thinking that there might be some risk in that distinction.

George Kateb: Yes, and you are not alone in thinking that.

Tomás Chuaqui: And some risk even to your own...

George Kateb: Project.

Tomás Chuaqui: Project. That's right. Existential values of identity, may have various sources.

George Kateb: Yes.

Tomás Chuaqui: You, I think, want to rescue those that have to do with individual values of identity.

George Kateb: Yes, rather than group.

Tomás Chuaqui: Rather than group; that's precisely where I'm going.

George Kateb: But I want to retain species identity. That's a separate issue.

Tomás Chuaqui: That's a separate issue, absolutely. But it may be the case, and I think it is more often than not the case, that values of identity are actually group-based.

George Kateb: Yes, in fact they are.

Tomás Chuaqui: In fact they are. And yet you -I don't think you say this in Human Dignity; I don't remember where you say something like this- but you say that group membership ought to be, and these are the words you used, "deliberately limited". It should be resisted.

George Kateb: Yes.

Tomás Chuaqui: Actively resisted.

George Kateb: Yes.

Tomás Chuaqui: It's kind of an attempt to resist one's own existential tendency, in a certain sense. For many, I would claim.

George Kateb: Yes... which is false; false identity.

Tomás Chuaqui: False identity, that's what I wanted to ask you about. How do you make that distinction between a false identity, and a true identity? Group identity being falsified, let's say, versus individual identity, which would be true?

George Kateb: Good! I think that in the essay "Notes on pluralism" (2008) I try to take up that question. Group identity seems to me to be an abridgment of one's identity, and it posits the thought, which is false, that I could be, or I could have been, only the group member that I am. So I speculate: suppose, as an infant, a baby is taken from one society to another. This baby is born, say, to French parents who then take the baby to some foreign country, or to some other condition of life, drastically raised or lowered. That baby would survive, let us say, and it is clear that it would be, in certain respects, different. Which is to say, I do not wish to deny, even if I seem to have done so, that of course we take on to some extent the coloration of our society, or even more; it's more than skin deep. I don't think I deny that. But the point is not to insist that unless my "Americanness" is respected as such, I'm being disrespected. Because I, as a baby, I could have been more like you, if you're coming from a different country, than not. But I have an indefinite repertory of possibility that my particular society in which I grew up does not exhaust. Therefore I must not be so tenacious to defend or assert it against other societies. The real motivating power is that people will fight over what they think to be themselves, when they're not fighting for themselves; they're simply fighting for what has happened to them, and it need not have happened. And you can resist it and fight it and throw it back, rather than being overcome by it. Yet it is the most natural mistake in the world, and the most inevitable. But at least a few people ought to say: there is more potentiality in you than can ever be realized and you did not have to be bound by what you accept now as yourself. You are inwardly more than you are willing to recognize or admit, and at the same time, to the extent that you fight for your group identity against others who threaten it, you are inwardly the same rather than striving to become distinct. You're inwardly the same as they are, because they have the same conviction about themselves that you do. So the French guy fights the German guy, and the German and the 
French guys are inwardly the same: they are both equally impassioned and committed to their group identity, in exactly the same way, -even though outwardly they are different because one is French and the other is German-, instead of cultivating their inwardness, which is the real point of democratic individuality. And seeing that, on the one hand, we are the same and should not be fighting, and, on the other hand, each one of us is individually different! Not different because -in any way that morally matters- we are French, or German, or Swedish, or whatever it is. Now, these are ideas that I've never worked out to my satisfaction or that of others. But the tension in the effort represents the tension in the facts, and I think you have to go to "Notes on Pluralism", that essay -it's one of the first five in Patriotism and Other Mistakes- where I say it's this and it's that, it's this and it's that: one's group character is contingent and is necessary, it is deep and it is shallow. But, the last word, maybe, has to be given to morality here, and not to anything else; and that is, it is group identity that accounts for much of the trouble of the world, much of the destruction of rights. It's a failure to recognize, on the one hand, common humanity, and, on the other hand, the distinctiveness of the individual, which transcends surface group differences... you are not persuaded now either...

Tomás Chuaqui: I'm getting there... I think this has to do with something you said yesterday which I found a little problematic. When we were talking about the sociological evaluation of constitutional democracies and their impact upon the development of democratic individuality as you think of it; when you talked about the US, you argued that in your view there were hardly any other societies which had resulted in the emergence of people who stood for their conscience.

George Kateb: Right, apart from religious martyrdom.

Tomás Chuaqui: Oh, apart from religious martyrdom...

George Kateb: ... which also used to be taken as an expression of conscience.

Tomás Chuaqui: That's right. Now, it's interesting that you actually compare it to martyrdom, because as Kant would say "we're not called upon to be saints or martyrs", right? This is supererogatory, no? It's beyond morality. And this is what concerns me. Your requirements for human -I'm not sure of calling them "requirements"- but your understanding of what it is that makes us dignified, is actually beyond morality, in a certain sense: the ability to stand on our own beliefs, and our own conscience. And this is...

George Kateb: .... relation to oneself.

Tomás Chuaqui: That's right.

George Kateb: Yes.

Tomás Chuaqui: I think Kant is already setting a very high standard for what makes us dignified. But you're actually raising the bar, it seems to me...

George Kateb: Oh, you do think so?

Tomás Chuaqui: Well, because you're claiming, I think, that dignity relates to something that is even beyond morality, beyond the requirements of morality.

George Kateb: Yes, Kant does tie them together, as I try to suggest. He eventually has them so mutually dependent that they become one concept rather than two.

Tomás Chuaqui: Morality and dignity, you mean.

George Kateb: Morality and dignity.

Tomás Chuaqui: That's right

George Kateb: Now you think I have made the demands on the self even harder than Kant has?

Tomás Chuaqui: Yes, because Kant would say that we are required to be moral, not martyrs or saints, whereas you connect dignity to our ability to be martyrs. Now, not everyone is called upon to be a martyr, but you do claim, I think, that everyone has a capacity to eventually be one, as a human being.

George Kateb: Well, certainly the capacities to treat others better than they are treating oneself, yes. Though not to the point, I think I'd say, not to the point of complete self-sacrifice or the point 
of martyrdom, but certainly going in the direction of the Good Samaritan. Yes, I do think the highest everyday morality is the Golden Rule: to treat others as you would be treated, not as you have been treated. On the Golden Rule Kant is very interesting and rather surprisingly reductive. In his Lectures on Ethics (2005) he confines the application of the Golden Rule to friends, which is exactly not the teaching of the Good Samaritan. The Samaritan is a heretical Jew, an outcast! On the other hand, Kant makes certain demands on people that I would never make: unconditional obedience to the State. And I assume he expects you to die for your country, and I would place that supposed obligation under a big question mark. But Tomás, I've not thought enough, I suppose, of what I have been trying to say in relation to the Kantian set of prescriptions. I've thought some about it, but I did not think that I was asking more of people, in certain directions, right? Not in all directions, in certain directions, more even than Kant is asking. So I have to think about that some more.

Tomás Chuaqui: You would resist, though, that claim? I mean, earlier you were very emphatic upon Obama's knowledge of the possibility of being shot, of being murdered.

George Kateb: Yes.

Tomás Chuaqui: And this was, in a sense, an example of a citizen of a constitutional democracy. I connected this to the claim you made before about standing for what you believe in and the demands of one's own conscience. Whenever you spoke about this ideal -if I may call it so-ideal citizen of a constitutional democracy, as one who stands for what they believe in, and defends their own conscience, it was linked to: Martin Luther King Jr., John Kennedy, Robert Kennedy, Obama as possibly being murdered, and so on, and so forth. That's why I made the connection.

George Kateb: Right. They all took risks. They didn't want to die, though. They were never faced with the demand: "shut up or we'll kill you". Whereas some martyrs were, in fact: "you must stop professing this faith;" the martyr says "no;" "then we'll kill you;" and the martyr says, "I accept the death". That's not quite what happened in the case of those who fought for civil -black rights, basically- all of whom in some way or another died for it. Not Obama, not yet. Thank heavens. I accept the categorical difference, the category difference, between being moral and being self-sacrificing, on the one hand, and being devoted and being a martyr on the other hand. I do accept J. O. Urmson's concept of the supererogatory, and indeed I've written about it in an essay on self-sacrifice and martyrdom that appeared in Social Research (2008), I think. I will, however, respect certain acts of martyrdom, and certain acts of self-sacrifice. But I would never make them obligatory. So that's not raising the demands, it's not in that direction, but rather in some other direction, a direction of greater thoughtfulness and inner withdrawal from what is around one. Kant never made that demand, I grant you. It is a secular Augustinianism. Or it is Stoic, if you will. It is to see oneself as never quite at home. If not a nomad or a pilgrim, never entirely at one with anything in one's life. Now, how do love and friendship fare in such a world? Love and friendship, I mean, that's a separate chapter in the Emerson book, and it has to be a separate chapter (2002). It is a question for any radical individualist of the sort that Emerson was. Love and friendship are their own world and they have their own rules. They are not "groupiness". They're one to one; it's an expression of being an individual. You don't have to have only one friend, or one beloved. But ideally these shatter -and here is the big word for a martyr of resistance to group identity- all conformity, the great sin of group identity. You can't have group identity unless everybody in the group thinks roughly the same thing about the most important matters. This is a nightmare! Friendship and love break this. Otherwise, try not to be at home in the world. Try not to fit in with the group. This doesn't mean you have to become a recluse, certainly not. That voids the whole effort; makes it, in one respect, too easy. No, you try not to be overcome, swept along, seduced too easily, enlisted too easily.

Tomás Chuaqui: How do you think that constitutional democracy promotes this inner withdrawal. I mean, I know you've written a lot about it. But I fail to see a direct connection between being a member of a constitutional democracy and achieving this, which I think is, I still insist, a higher requirement.

George Kateb: Yes it is. 
Tomás Chuaqui: Very few people, I would say, have this aptitude to withdraw from the world and at the same time achieve friendships, love, a sense of responsibility for others. Most of those who withdraw from the world are psychopaths, and we don't want that at all, do we?

George Kateb: Oh, my god! Now we are playing a little rough (laughs)...

Tomás Chuaqui: Well, that's withdrawal from the world for you, right?

George Kateb: Wouldn't you say?... You began with asking about the link between being a citizen in a constitutional democracy and this inner elevation or this concentrated inwardness. I think constitutional democracy in all that it does, teaches the lesson that you must take yourself seriously in certain respects. The first respect, the first way, is certainly as important as any, which is, do not accept an abridgement of your rights, take yourself seriously to the point that you want your rights unabridged and protected so that you may exercise whatever right matters to you at any given time. Take yourself seriously, don't be used, don't be abused. That's the beginning. You have to go then in a certain direction in taking yourself seriously, the synonym for which is care for the self, which we talked about yesterday. If you take yourself seriously, and insist that you not be used or abused by others or by the State -and of course you'll try very hard not to abuse others as a person, and you'll try very hard to resist being enlisted in the abuse of others by your State, whether those others are at home or abroad- you then will (and here Thoreau is an exemplary American figure) resist when you have to resist. I'm not saying to the point of selfsacrifice or martyrdom. Eventually what accompanies this sense is a determination always to think for oneself. And from thinking for oneself -not necessarily, but possibly- will follow magnanimity; anti-chauvinism; anti-social arrogance; anti-persecution of people different from oneself, either as individuals or in groups; and, though not as a matter of logic, a commitment to nonviolence. I say to you, you don't have to be a citizen of a constitutional democracy to follow that path. But I know of no other society, historically speaking, that addressed itself to all persons. And indirectly or directly, explicitly or tacitly, encouraged them to take themselves seriously, not to let themselves be used or abused, not to be too easily seduced or enlisted, and to show generosity of perception and magnanimity of conduct. It is no accident, a phrase that Stalin used, but of course not about our case, that Socrates was an Athenian.

And now, how about conscience in the modern world? It's basically Protestant, it did not begin in a democracy, but when it became politicized it produced the theory of toleration, and the theory of rights, and the theory of universal suffrage. It aspired to a democratic republic out of the sense that this would be the society which best facilitated care for the self, taking yourself seriously, being magnanimous towards other selves, and generous in your receptivity and response to their differences from you. The connection isn't tight; but it is not merely contingent, it is not merely accidental.

Tomás Chuaqui: I'm sorry to ask this again, but how is that outlook not -I am going to use the word again- a perfectionist political theory? In the sense that you justify constitutional democracy in the light of the kind of people it produces.

George Kateb: Not solely justify. Because the other part of the argument is: I want my rights; I know you want yours too and I will respect them, and hope that the State above all respects the rights of all of us, not just of me. But then my rights are in part protection against needless suffering, and that's the moral part of it. And I would never drop that, or even subordinate it. So it can't be just perfectionism, it can't just be the positive achievement of one's highest attainment. Even if I waste my life, provided I do not harm others, my rights must be respected. Because I am a human being, and who knows what might happen to me that would pull me out of this wasting of one's life, or mediocrity, or some other thing. Liberty is not just for a few. And in the Emersonian line, this awareness of one's infinitude, to use Emerson's word, one's potentiality, and yet the wastefulness of much of one's life, this tension is acknowledged and fought against. But the Emersonians never drop liberty and respect for rights, because so many people seem to be not using their rights or using them poorly -"though to cheap ends" is the phrase that Emerson uses for the run-of-themill. They also did believe -Emerson, Thoreau, and Whitman- that sometimes you're at your best only in moments or episodes. I don't think that satisfies a perfectionist. 
Tomás Chuaqui: Well, but there might be a kind of perfectionism that would claim that the reason you respect others is because every once in a while, no matter how far in between, you do have these great moments.

George Kateb: Yes, ok.

Tomás Chuaqui: And you would accept that view?

George Kateb: Right. But that's not a perfectionist view.

Tomás Chuaqui: No?

George Kateb: Because it's episodic. I'm not a work of art if most of the time I'm a piece of junk, but only have moments when I strike others as having really achieved myself or achieved the work worth achieving. And much of the time it's -it has to be- all ill-defined, as a work of art is not. Ill-defined, or undefined, or vague; or, therefore, a life of wasted opportunity, or selfindulgence, or licentiousness. Though not illegal, nevertheless, morally, or psychologically, or characterologically, unvirtuous. "Come on, you can do better than that!", you say to yourself or to someone else. "I'm not going to force you, not going to put you in prison if you're not achieving your best, but... you're better than that". So much of anyone's life is waste, how could one ever aspire to be like a work of art. It's an inhuman ideal; it's an inhuman, inhuman discipline. It's false to the facts: that's not the way potentiality would manifest itself. You have your good moments, and your good periods of time. And who is perfect, anyway? I mean that's, that's quite a word.

Diego Rossello: Can I ask you what you think of Michael Rosen's book, Dignity: Its History and Meaning (2012)?

George Kateb: It is a very readable book. It's done with care and intelligence. It's nicely written... If I had any negative point it would be that I wish it were more ambitious. Now, it is against the English grain, certainly if you're a professional philosopher -as Michael Rosen is, and a very good one- to bite off more than you can chew. But you know there is such a thing as biting off more than you can chew and still try to make the best of it. Because you feel that unless you face certain questions, though they are beyond your capacity, you're not doing all that you could do, in the subject you've undertaken. So, this is a very good book, it is worth reading. I just wish it were somewhat more ambitious.

Tomás Chuaqui: Could I ask one last big question? It has to do with the means-ends issue you mentioned before. And I think it's related to what you were just saying about perfectionism. I want to connect it with something that apparently has nothing to do with it, but I think there is a connection. The book edited by Villa and Sarat (1996)...

George Kateb: Yes. Amherst College. Villa was a student of mine at Amherst College when he was an undergraduate and we became friends, close friends, and intellectual friends. Sarat teaches public law. He has a law degree from Yale. My department hired him in 1974 as a really young vigorous fellow, and he has been at Amherst ever since. And he has published enormous amounts. He and Dana surprised me -but I'm sure it was Austin Sarat's idea- with this enormous, bulky, manuscript. The very idea of such a book was kept from me.

Tomás Chuaqui: Oh, really?

George Kateb: I was truly honored by it.

Tomás Chuaqui: It's a very nice collection; it is very, very good.

George Kateb: It is, it is indeed. It's a very interesting collection, and some wicked things are said about me in this book, and sometimes I'm wickedly disregarded altogether... Dana Villa's introduction, I would say, using the category of "modernist"... I wish I were good enough to be a modernist in political theory. But that... that sort of gets me right; yes, good.

Tomás Chuaqui: So, actually talking about the Introduction, they claim, going back to that early book Political Theory: its Nature and its Uses (1968), that your implicit adversary is Weber. In fact, in the book you don't, as far as I remember, even mention Weber. And the claim is that in that book you are trying to say that political science can -it's a simplistic way of putting it- but can never be value free, and that it must be morally informed, whereas Weber would have argued differently. 
It seems questionable that that's actually a proper characterization of Weber, particularly if one is thinking of the essay "Politics as a Vocation"(2004)...

George Kateb: Right.

Tomás Chuaqui: And when you were speaking about conscience you reminded me of that essay. In the sense that there is this argument that politics - and this is the part I don't think you would accept- that politics is about ends and that the political agent must think about ends and be responsible for them. But there's a point when conscience intervenes, and that is the moment at which Weber seems to claim he has most respect for anyone...

George Kateb: He does say that...

Tomás Chuaqui: And that is the moment when a really "mature" human being, that is the word he uses, comes out and says, well, "here I stand I can do no other"- the phrase attributed to Martin Luther. So I wondered if you would, first, agree with the claim that Villa and Sarat make that your implicit adversary is Weber; and, second, whether you accept the interpretation of Weber I've just given, seeing the connection between your ideas and his views.

George Kateb: That really is, as usual, a very good question. My thoughts about Weber are not disciplined, and I've never worked them out, and I've never written about Weber at any length. Though I do take him up in an essay called "Democracy and Untruth" (2012), which appeared last year in a journal called Raritan. Now, I think that first of all I would say that Weber's preferred response to political life is attention not to ends so much as consequences, and the ethics of responsibility pertains to being constantly aware of the consequences of what you do, which then seems to include a realization that what you think is good could have bad consequences, and what you think is bad could have good consequences. This is a valuable teaching, and I would never reject it. What I find problematic in Weber, beginning with the essay "Politics as a Vocation" (I still prefer that as the translation of "Politik als Beruf") is that he, without either self-examination or scholarly examination, takes for granted that the highest responsibility for a person in politics is the preservation of -now you need two nouns, not one- the State, and the preservation of the Society. In turn what that means is: the State is an end in itself vis-a-vis other States, and the Society is an end in itself vis-a-vis other societies. You don't have to go to Schmitt for this. Weber is already saying what Schmitt then says in The Concept of the Political (2007). If I'm anti-Weberian, despite my tremendous respect for him as a prodigious scholar and thinker, greatly influential over people-influenced by Nietzsche he then influences Heidegger and Arendt, even though they rarely mention him- it seems to me, if I am to be skeptical towards Weber, and especially in that essay, it is not because of his insistence on the importance of attention to consequences; rather, it is his unexamined commitment to the State; his State as such, and his Society as such, generalized. So that everybody, anywhere must have, if they are to be responsible, a commitment to the State as such and to the Society as such. It seems to me, I cannot, believing in human dignity as I do, and being skeptical towards group identity as I am, accept one's State as an irreducible value, and one's Society as either derivatively or connectively -either way- as an end in itself. I can't. It is not compatible with human dignity to entertain these two thoughts. Now, I don't recall, does Villa take up this issue of the State as such?

Tomás Chuaqui: No, his claim is that you're arguing against the idea that there can be a valuefree social science.

George Kateb: Good, that's then Weber in, maybe, "Science as a Vocation" (2004), and in his general practice.

Tomás Chuaqui: And he puts you together with Voegelin and Strauss doing this job...

George Kateb: I don't mind, it's good company, though I didn't use to think so (laughs). Right, I would say that Weber misrepresents himself, in some respect. He's right that being partisan, being polemical, being narrow-minded are incompatible with true understanding. On the other hand, what his life work shows is a continuous receptivity and responsiveness, to things that have nothing to do with his own society. Isn't that a value? The value is responsiveness, receptivity. These are the values of Emerson and Whitman, if not Thoreau. Thoreau is responsive only to nature and extreme human suffering, but not to the variety of human achievement. So, notice 
what we have said about Weber: two things. In "Politics as a Vocation" he does not examine his commitments, and he has them, and he is not value-free. Second, in his scholarship he has not examined his commitment, and he has one, which is to be receptive, and responsive, and generous, in your understanding of what is other. So, Weber is worth reading and thinking about, but one, there are commitments there that he has and does not state. Two, he was himself an awful patriot, and was horrified by German defeat in the First War, and never got over it. And then he dies, what, in 1920 is it? Something like that? He was mortally wounded by German defeat, and he went crazy. That's OK. His life is justified. Not by his fulminations after the war, but by the truly exemplary life of understanding that he led. Nobody quite like him. Not since, anyway. And most of those who use him try to make him into a mere positivist. He is not. He is soaked in certain values. But, one set of those values is not admirable: the commitment to the State as such, and to the Society as such. And then it shows itself in his horror -that's the connection- in his horror at German defeat. "Horror" is not too strong a word. And he goes somewhat off the rails. Great thinker, great thinker. Not possible without Nietzsche. I think he says so. And certainly worthy of a more generous kind of attention than he has received, at least characteristically. He's too good for the positivists. I have no doubt about that. He's a real thinker.

Diego Rossello: I am tempted to add one thing. It's not a question, it's just a comment. It seems that Dana Villa has a point when he says that you can be read as an anti-Weberian because, whereas Weber writes about politics as a vocation and science as a vocation, you have been using the vocabulary of the "vocation of humanity" and the "vocation of man". So, in a way, it seems that Human Dignity is a treatise about the vocation of being human.

George Kateb: Yes, that's right.

Diego Rossello: Not of being political; in politics, or a scientist.

George Kateb: Yes, I agree, though I respect certainly the vocation of the scientist. I respect the pursuit of understanding as a vocation. I do indeed. Do I respect the life in politics as a vocation? I incline, generally, to seeing it as a necessary evil. So though I admire Hannah Arendt greatly, I do not accept her teaching that politics is an end in itself, and that it has its own code of morality, unaffected by other morality. She didn't even believe that in other things she wrote at the same time. The fragmentary book on morality -it's in one of the posthumous collections-, edited by Jerome Kohn, not The Promise of Politics (2007), but Responsibility and Judgment (2003) that she puts forth her thoughts on morality. They're very interesting! Very interesting. And they are not confined to saying "politics has its own morality", as she says in The Human Condition (1999), where promising and forgiveness constitute political morality, the morality appropriate to political action. ... Forgiveness plays no role in her theory of politics; promise-keeping does. It's what binds a group of individuals together: "we promise to be with each other when it counts". It's not solidarity so much, it's not really solidarity. It is individuals freely coming together to engage in political discourse over the common good, and staying with each other through thick and thin. Not defecting, not withdrawing. Being there.

Diego Rossello: I think we have broken the promise of finishing at eleven (laughs).

George Kateb: It never was a promise...

Tomás Chuaqui: It was an implicit promise.

Diego Rossello: Thank you so much for this.

George Kateb: Thanks must be mine.

\section{REFERENCES}

Anderson, Ryan T. 2012. Review of Human Dignity, in First Things: A Monthly Journal of Religion and Public Life (Feb. 2012) 220: 65.

Auden, W.H. 1990. The Dyer's Hand and Other Essays (1962). New York: Random House USA Inc. Arendt, Hannah. 1999. The Human Condition (1958). Chicago: University of Chicago Press. 
Arendt, Hannah. 2003. Responsibility and Judgment. New York: Schocken Books.

Arendt, Hannah. 2007. Promise of Politics. New York: Schocken Books.

Camus, Albert. 2008. The Plague (1947). London: Penguin Books.

Cavell, Stanley. 1990. Conditions Handsome and Unhandsome: The Constitution of Emersonian Perfectionism: The Carus Lectures (1988). Chicago: University of Chicago Press.

Derrida, Jacques. 1984. Margins of Philosophy. Chicago: University of Chicago Press.

Derrida, Jacques. 1989. Of Spirit: Heidegger and The Question: Chicago: University of Chicago Press. Derrida, Jacques. 2001. Writing and Difference. London: Routledge.

Dewey, John. 2008. The Collected Works of John Dewey: 1938-1939, Experience and Education, Freedom and Culture, Theory of Valuation, and Essays v. 13, edited by Jo Ann Boydston. Carbondale: Southern Illinois University Press.

Dewey, John. 2009. Individualism Old and New \& Liberalism and Social Action \& A Common Faith (1930). Denver: Frederick Ellis.

Dewey, John. 2009. Art as Experience (1934). New York: Perigee Books U.S.

Emerson, Ralph Waldo. 2004. Representative Men: Seven Lectures (1850). New York: Random House USA Inc.

Foucault, Michel. 2005. The Hermeneutics of the Subject: Lectures at the Collège de France 1981-1982. London and New York: Picador.

Foucault, Michel. 2011. The Government of Self and Others: Lectures at the College de France, 19821983 (Lectures at the Collège de France). London and New York: Picador.

Foucault, Michel. 2012. The Courage of Truth: The Government of Self and Others II; Lectures at the Collège de France, 1983-1984 (Lectures at the College De France, 1983-1984). London and New York: Picador.

Frank, Jason, ed. 2013. A Political Companion to Herman Melville (Political Companions to Great American Authors). Kentucky: The University Press of Kentucky.

Frost, Robert. 2002. "The Armful", in The Poetry of Robert Frost: The Collected Poems, Complete and Unabridged, edited by Edward Connery Lathem (1928). New York: St. Martin Press.

Heidegger, Martin. 1976. What is Called Thinking? New York: Harper Perennial.

Heidegger, Martin. 2000. Introduction to Metaphysics (1935). New Haven: Yale University Press.

Heidegger, Martin. 2010. Being and Time (1927). Albany, NY: State University of New York Press. James, Henry. 2008. The Wings of the Dove (1902). London: Penguin Books.

James, Henry. 2012. The Portrait of a Lady (1881). London: Penguin Books.

Kant, Immanuel. 1998. Groundwork of the Metaphysics of Morals (1785). Cambridge: Cambridge University Press.

Kant, Immanuel. 2005. Lectures on Ethics. Cambridge: Cambridge University Press.

Kateb, George. 1961. "Aspects of Rousseau's Political Thought". Political Science Quarterly 76 (4): 519-543.

Kateb, George. 1968. Political Theory; Its Nature and Uses. New York: St. Martin Press.

Kateb, George. 1986. "Rigidities in the Study of Political Theory". In Tradition, Interpretation, and Science: Political Theory in the American Academy (Suny Series in Political Theory: Contemporary Issues), edited by John S. Nelson. New York: State University of New York Press.

Kateb, George. 1972. Utopia and its Enemies (1963). New York: Schocken Books.

Kateb, George. 1994. The Inner Ocean (1992). Ithaca: Cornell University Press.

Kateb, George. 2002. Emerson and Self-Reliance (1994). Lanham, MD: Rowman \& Littlefield.

Kateb, George. 2008. Patriotism and Other Mistakes (2006). New Haven: Yale University Press.

Kateb, George. 2008. "Morality and Self-Sacrifice, Martyrdom and Self-Denial". Social Research 75 (2): 353-394. 
Kateb, George. 2011. Human Dignity. Cambridge, Mass.: Harvard University Press.

Kateb, George. 2012. "Democracy and Untruth". Raritan 31 (3).

Levine, Alan M. A. and Daniel S. Malachuk (Editor). 2014. Political Companion to Ralph Waldo Emerson (Political Companions to Great American Authors). Kentucky: The University Press of Kentucky.

Marx, Karl. 1978. "For a Ruthless Criticism of Everything Existing", in The Marx-Engels Reader, Edited by Robert C. Tucker. New York: W. W. Norton \& Company, pp. 12-15.

Melville, Herman. 1986. Billy Budd and Other Stories. New York and London: Penguin Classics.

Melville, Herman. 2008. Moby-Dick (1851). Oxford: Oxford University Press.

Mill, John Stuart. 2003. Utilitarianism (1863) and On Liberty (1859): Including 'Essay on Bentham' (1838) and Selections from the Writings of Jeremy Bentham and John Austin, edited by Mary Warnock. MA Malden: Blackwell Publishing Ltd.

Murphy, Liam and Thomas Nagel. 2004. The Myth of Ownership: Taxes and Justice. New York: Oxford University Press.

Nehamas, Alexander. 1985. Nietzsche: Life as Literature, Cambridge: Harvard University Press.

Neumann, Franz. 2009. Behemoth: The Structure and Practice of National Socialism (1942). Chicago: Ivan R. Dee.

Nietzsche, Friedrich. 2013. On the Genealogy of Morals (1887). London: Penguin Books.

Nozick, Robert. 2013. Anarchy, State, and Utopia (1974). New York: Basic Books.

Rawls, John. 1958. "Justice as Fairness", The Philosophical Review, Vol. 67, № 2. (Apr., 1958): 164-194.

Rawls, John. 1971. A Theory of Justice. Cambridge, Mass.: Harvard University Press.

Rawls, John. 1991. Two Concepts of Rules (1955). New York: Arden Media U.S.

Rawls, John. 1993. Political Liberalism. New York: Columbia University Press.

Rawls, John. 2001. Law of Peoples (1999). Cambridge, Mass.: Harvard University Press.

Rawls, John. 2001. Justice as Fairness: A Restatement. Cambridge, Mass.: Harvard University Press.

Rawls, John. 2008. Lectures on the History of Political Philosophy, edited by Samuel Freeman. Cambridge, Mass.: Harvard University Press.

Rorty, Richard. 1989. Contingency, Irony, and Solidarity. Cambridge: Cambridge University Press.

Rorty, Richard. 1991. "Heidegger, Contingency, and Pragmatism" in Essays on Heidegger and Others, 27-49. Cambridge: Cambridge University Press.

Rorty, Richard. 1991. "The Priority of Democracy to Philosophy" in Objectivism, Relativism and Truth. Cambridge: Cambridge University Press.

Rorty, Richard. 1999. Achieving Our Country: Leftist Thought in Twentieth-Century America. Cambridge, Mass.: Harvard University Press.

Rorty, Richard. 2009. Philosophy and the Mirror of Nature (1979). New Jersey: Princeton University Press. Rosen, Michael. 2012. Dignity: Its History and Meaning. Cambridge, Mass.: Harvard University Press. Sarat, Austin and Dana Villa. 1996. Liberal Modernism and Democratic Individuality: George Kateb and the Practices of Politics. New Jersey: Princeton University Press.

Sartre, Jean-Paul. 2003. Being and Nothingness (1943). London: Routledge.

Schmitt, Carl. 2007. The Concept of the Political (1932). Chicago: University of Chicago Press.

Seery, John E (Editor). 2014. A Political Companion to Walt Whitman (Political Companions to Great American Authors). Kentucky: The University Press of Kentucky.

Shklar, Judith. 1985. Ordinary Vices. Cambridge, Mass.: Harvard University Press.

Shklar, Judith. 1989. "The Liberalism of Fear" in Liberalism and the Moral Life, edited by N. Rosenblum. Cambridge, Mass.: Harvard University Press.

Stone, Robert. 1985. “The Art of Fiction No. 90, Interviewed by William C. Woods”. Winter 1985, $\mathrm{N}^{\mathrm{o}} 98$. 
Thoreau, Henry D. 2006. On the Duty of Civil Disobedience (Walden) (1849). Cirencester: The Echo Library.

Tolstoy, Leo. 2009. War and Peace (1869). London: Penguin Books.

Trotsky, Leon. 2000. Their Morals and Ours: The Marxist View of Morality (1938). Broadway: Resistance Books.

Weber, Max. 2004. The Vocation Lectures: "Science as a Vocation"; "Politics as a Vocation" (1919). Cambridge, Mass.: Hackett Publishing Co, Inc.

Weil, Simone. 1951. Intuitions Pré-Chrétiennes. Paris: La Colombe.

Weil, Simone. 1981. The Iliad or the Poem of Force (1939). Wallingford, PA: Pendle Hill Pamphlet.

Wilde, Oscar. 2003. The Picture of Dorian Gray (1891). London: Penguin Books.

Zakaras, Alex. 2010. Individuality and Mass Democracy: Mill, Emerson, and the Burdens of Citizenship. New York: Oxford University Press.

George Kateb is William Nelson Cromwell Professor of Politics, Emeritus, at Princeton University. Professor Kateb is an influential political theorist with an international reputation. He is the author of Utopia and Its Enemies (1963); Political Theory; Its Nature and Uses (1968); Hannah Arendt: Politics, Conscience, Evil (1984); The Inner Ocean: Individualism and Democratic Culture (1992); Emerson and Self-Reliance (1994); Patriotism and Other Mistakes (2006); and Human Dignity (2011).

Tomás Chuaqui Henderson is associate professor of political science at the Pontificia Universidad Católica de Chile. Ph.D. in Political Science, Princeton University. E-mail: tchuaqui@uc.cl

Diego Rossello is assistant professor of political science at the Pontificia Universidad Católica de Chile. Ph.D. in Political Science, Northwestern University. E-mail: drossello@uc.cl 
